\title{
A Characterization of a Cool-Climate Organic Vineyard's Microbiome
}

\author{
A. Harrison Wright, ${ }^{1, \dagger}$ Shawkat Ali, ${ }^{1}$ Zoë Migicovsky, ${ }^{2}$ Gavin M. Douglas, ${ }^{3}$ Svetlana Yurgel, ${ }^{2}$ Adèle Bunbury-Blanchette, ${ }^{4}$ \\ Jeff Franklin, ${ }^{1}$ Sarah J. Adams, ${ }^{5}$ and Allison K. Walker ${ }^{5}$ \\ ${ }^{1}$ Kentville Research and Development Centre, Agriculture \& Agri-Food Canada, Kentville, Nova Scotia, B4N 1J5, Canada \\ ${ }^{2}$ Department of Plant, Food, and Environmental Sciences, Faculty of Agriculture, Dalhousie University, Truro, Nova Scotia, B2N 5E3, \\ Canada \\ ${ }^{3}$ Department of Microbiology \& Immunology, Faculty of Medicine, Dalhousie University, Halifax, Nova Scotia, B3H 4H7, Canada \\ ${ }^{4}$ Department of Biology, Saint Mary's University, Halifax, Nova Scotia, B3H 3C3, Canada \\ ${ }^{5}$ Department of Biology, Acadia University, Wolfville, Nova Scotia, B4P 2R6, Canada
}

Accepted for publication 26 July 2021.

\begin{abstract}
The microbiome, an influential factor affecting plant health and growth, is attracting increasing interest with respect to wine grape production. The purpose of this study was to characterize the microbiome (fungi and bacteria) of the soil, cover crop roots, and grape (Vitis spp.) roots across rootstock and depth in a cool-climate, organic vineyard. The cover crop consisted of a fescue (Festuca sp.) grass, while grape roots were sampled from New York Muscat, a cool-climate hybrid, across three root types (ungrafted, 3309C and Riparia Gloire) at three root depths ( 0 to 15,15 to 30 , and 30 to $50 \mathrm{~cm}$ ). The grape root microbiome was more specialized, with fewer observed amplicon sequence

Niastella, and Rhizobium; most prominent fungal genera were Plectosphaerella, Trichosporon, and Ilyonectria. Although no correlations were found between $\boldsymbol{\alpha}$-diversity metrics and soil parameters, Pseudaleuria relative abundance was correlated with $\mathrm{Mn}, \mathrm{Fe}$, and $\mathrm{Na}$ levels. Soil depth explained a small portion of bacterial but not fungal variance and taxonomic composition. Rootstock type explained a portion of both bacterial and fungal variance and taxonomic composition, substantiating the role of host plant genetics in the development of the grape root microbiome. This is the first characterization of the grape root microbiome in a cool-climate Canadian vineyard.
\end{abstract} variants for both bacteria (16S) and fungi (internal transcribe spacer) than found in the cover crop and the surrounding soil. Grape roots were dominated by bacterial genera Pseudomonas,
Keywords: agriculture, bacteriology, microbiome, mycology, plants
Grapevines (Vitis spp.) are readily colonized by both symbiotic bacteria and fungi (Baldan et al. 2014; González and Tello 2011; Linderman and Davis 2001). This microbial activity is fundamental to plant health and development, and to grape production, quality,

†Corresponding author: A. H. Wright; harrison.wright@ canada.ca

A. H. Wright and S. Ali contributed equally to this work.

Funding: Z. Migicovsky was supported by National Science Foundation Plant Genome Research Project 1546869. A. H. Wright and S. Ali were funded by Agriculture and Agri-Food Canada through New Scientist funds as well as by the Department of Agriculture, Nova Scotia. A. K. Walker gratefully acknowledges the Acadia University 25.55 University Research Fund and NSERC Discovery Grant (number NSERC-2017-04325).

*The $\boldsymbol{e}$-Xtra logo stands for "electronic extra" and indicates that supplementary tables, supplementary figures, and supplementary files are published online.

The author(s) declare no conflict of interest.

(C) Her Majesty the Queen in Right of Canada, as represented by the Minister of Agriculture and Agri-Food Canada, 2022. and characteristics (Barka et al. 2000; Bokulich et al. 2016; Linderman and Davis 2001; Pinto and Gomes 2016). In particular, the root and soil microbiome affects soil characteristics, nutrient and water uptake, and disease pressure, and may act as a reservoir for microorganisms that go on to colonize the phyllosphere (Zarraonaindia et al. 2015).

Microbes of particular interest include plant-growth-promoting (PGP) bacteria. Promising genera include Azotobacter, Azospirillum, Bacillus, Pantoea, Pseudomonas, and Rhizobium (Ferreira et al. 2019). PGP bacteria may benefit plant growth and health through different modes of action. Biofertilizers can improve the uptake of key nutrients such as nitrogen, sulfur, and phosphorous by transforming the nutrients into forms that are available for uptake by the plant. Biostimulators can enhance plant growth through the synthesis of phytohormones such as auxins and cytokinins. Finally, biocontrol microorganisms may protect the plant from pathogens via various mechanisms such as competition or the production of antibiotics or protective enzymes (Ferreira et al. 2019). Similarly, arbuscular mycorrhizae fungi (AMF) are another group of beneficial microbes. These fungi have been shown to improve water and 
nutrient uptake, especially phosphorous, and to improve soil structure. As such, AMF are a common target of viticulture studies that investigate the beneficial relationship between these fungi and vines (Possingham and Obbink 1971; Schreiner and Mihara 2009; Trouvelot et al. 2015; Valentine et al. 2006).

Although the makeup of a plant's microbiome can influence a plant's growth and development, the opposite is also true. The genetics of the plant host, which can influence the nature of the exudates secreted by the root as well as the root structure and morphology, is an influential factor in shaping the host's microbiome (Babalola et al. 2020; Bulgarelli et al. 2013; Pascale et al. 2020). As such, when exploring the microbiome of our cool-climate vineyard, we might expect to find differences between the microbiome in the roots of the cover crop and of that of the grape, or even between grape root types. Additionally, with strong gradients in $\mathrm{pH}$, nutrient levels, and organic matter often existing in the soil column, this also offers an interesting avenue to explore.

Improved protocols and lower sequencing costs have resulted in a moderate though far from excessive number of studies in the literature that already explore the vineyard microbiome, including that of the grape roots (Berlanas et al. 2019; Martínez-Diz et al. 2019; Zarraonaindia et al. 2015). However, more studies are needed as we endeavor to better understand the relationships that exist between grapevines and their microbiome. In much the same way that an ecosystem may vary completely in the particular fauna and flora that make it up but still perform the same key functions such as nutrient cycling and energy flow through the food chain, a plant's microbiome may also be a product of its environment. As such, an examination of the microbiome found in a vineyard located in Nova Scotia would be a unique addition to the studies already found in the literature.

Some of the first vines to be planted in Canada, and among the first in North America, were done so in Nova Scotia. These early vineyards were established by French colonists in the $1600 \mathrm{~s}$ (Naugler et al. 2004). In the years that followed, grape growing in Nova Scotia was long a sideline devoid of commercial success; however, in recent decades, Nova Scotia's grape industry, buoyed by both a strong buy-local movement and, conflictingly, global warming, has experienced a period of robust expansion and growth, and now contributes over \$218 million annually to Nova Scotia's economy (Rimerman 2015). Nonetheless, with a limited amount of heat (region I according to the heat summation-based Winkler Index), the region remains on the periphery of where wine grapevines are commercially grown. The primary objective of this study was to be the first to characterize the microbiome (bacteria and fungi) in a coolclimate Canadian vineyard, including that of the soil and the roots of both the grapevines and the cover crop. Our secondary objective was to further characterize the grape root microbiome across (i) three different root types (ungrafted, 3309C, and Riparia Gloire) and (ii) at three soil depths (0 to $15 \mathrm{~cm}, 15$ to $30 \mathrm{~cm}$, and 30 to $50 \mathrm{~cm}$ ).

\section{MATERIALS AND METHODS}

Site and plant material. The grapevines were planted at a site located in Avonport, Nova Scotia, Canada, in June 2013 as part of a broader rootstock trial, with the hybrid cultivar New York Muscat grafted to Riparia Gloire and 3309C, as well as grown on their own roots (ungrafted). The 3309C rootstock is the most commonly used in Nova Scotia, as well as the northeastern United States, while Riparia Gloire is either the second or third most common rootstock used. Each scion-rootstock combination was planted in adjacent blocks consisting of two rows each; the rows were approximately $150 \mathrm{~m}$ long. Vineyard spacing was $140 \mathrm{~cm}$ between vines and $3 \mathrm{~m}$ between rows, with four vines per panel (i.e., between posts). The rows were oriented north-south on a slight, south-facing slope. Weather data from a nearby Environment Canada weather station (Kentville, Nova Scotia), indicate annual averages of 1,158 growing degree days $\left({ }^{\circ} \mathrm{C}\right)$ during the growing season, 158 frost-free days, and 1,208 $\mathrm{mm}$ of rain based on the past 10 years (2011 to 2020).

The vineyard was managed under organic or biodynamic principles. The primary sprays used in the vineyard were sulfur and copper based. No herbicides were used; weed control was accomplished via several passes a year with a knife hoe. Rows were hilled (i.e., the graft unions covered with soil) in the fall and dehilled in the spring. For each root type, two panels approximately $100 \mathrm{~m}$ apart from each other were randomly selected, one from each row. For each panel, 2 of the 4 vines were randomly selected to be included in this trial, for a total of 12 vines.

Soil analysis. The soil type at this site is a Gleyed Sombric Brunisol (Soil Classification Working Group 1987), locally known as Woodbourne (Holmstrom and Thompson 1989). These soils are moderately well to imperfectly drained, with approximately $50 \mathrm{~cm}$ of hard-setting, coarse, loamy-gravelly upper soil material. The lower soil material $(>50 \mathrm{~cm})$ is a firm, fine, loamy-gravelly till. Soil samples were taken before bud break in the second week of May 2018; six cores located within $0.5 \mathrm{~m}$ of the trunk of each of the 12 vines were taken, in a radial manner, to a depth of $0.5 \mathrm{~m}$ using a 1-in. open-faced gouge probe driven with a rubber mallet. Each core was divided into three depths ( 0 to 15,15 to 30 , and 30 to $50 \mathrm{~cm}$ ) and used to generate three composite samples for each vine. The samples were mixed thoroughly and sent to the Nova Scotia Department of Agriculture analytical lab (Truro, Nova Scotia) for soil analysis (i.e., macro- and micronutrients, $\mathrm{pH}$, organic matter, and cation exchange capacity).

Terrestrial subsurface microbiome sampling. Tissue sampling occurred at the same time as soil sampling. The soil was carefully removed around the trunk of each vine using a shovel and hand spades. A 1 m-by-1-m square was excavated down to a depth of $50 \mathrm{~cm}$. A representative sample of fine roots for microbiome analysis was obtained from each vine from each of the three soil depths used for the soil analysis described above (i.e., 0 to 15,15 to 30 , and 30 to $50 \mathrm{~cm}$ ) for a total of 36 samples (12 vines $\times$ three depths). Soil and microbiome samples were taken within the same 2-day period. All the root material associated with the vine within the pit was collected and its mass recorded. In addition to this sampling, a bulk soil sample intended for microbiome analysis was also collected at each of the three depths from one representative vine from each of the three root types, for an additional nine samples. Finally, roots were collected from the dominant cover crop species, a perennial fescue grass established at the time of planting. Samples were collected to a depth of $15 \mathrm{~cm}$, which contained the bulk of the cover crop roots, in the aisleway approximately $1.5 \mathrm{~m}$ from the nearest vine, adjacent to the six vineyard panels sampled.

Root tissue and bulk soil sample preparation. Larger grape roots ( 3 to $5 \mathrm{~mm}$ in diameter) were cut into $7-\mathrm{cm}$ pieces and placed into 50-ml disposable Falcon tubes with $40 \mathrm{ml}$ of $10 \%$ sterile glycerol. The tubes were vortexed vigorously to remove the soil from the roots. The roots were then transferred to a new tube using flamed forceps and washed three times in sterile ultrapure water (Nanopure D11971; Barnstead, Van Nuys, CA, U.S.A.), or until the water cleared. The roots were then further cut into $2.5-\mathrm{mm}$ pieces with a sterile, single-sided razor blade; $250 \mathrm{mg}$ of tissue was placed into 2-ml microcentrifuge tubes with two sterilized 5-mm steel balls and stored at $-80^{\circ} \mathrm{C}$. Upon removal, the roots were submerged in liquid nitrogen until the boiling stopped. The samples were then macerated (Tissuelyser II; Qiagen, Hilden, Germany) using 2-by-60-s cycles at 30 beats/s. The samples were submerged in liquid nitrogen between cycles. Performing this procedure twice completed sample maceration. 
For bulk soil sample preparation, $5 \mathrm{~g}$ was passed through a 2-mm sieve and freeze dried for $36 \mathrm{~h}$. A 25-mg sample of the resulting powder was transferred to $2-\mathrm{ml}$ tubes and stored at $-80^{\circ} \mathrm{C}$ prior to DNA extraction.

DNA extraction and sequencing. For root tissue, the DNA was extracted using the DNeasy Plant Mini Kit (Qiagen, Hilden, Germany) using the manufacturer's protocol, with the following modifications. Buffer AP1 with RNase was added to the sample tube and placed on the Tissuelyser II for one cycle, as described above. After completion of the cycle, the suspension was incubated at $65^{\circ} \mathrm{C}$ for $10 \mathrm{~min}$. DNA was eluted from the Mini spin column with a single $100-\mu$ l wash of AE buffer.

For bulk soil samples, the DNeasy PowerSoil Kit (catalog number 12888-100; Qiagen, Valencia, CA) was used for the DNA extraction following the manufacturer's protocol, with slight modifications to increase the yield and get high-quality DNA. The buffer from the Power Bead tubes was used for washing the soil slurries into the Power Bead tubes. After adding $60 \mu \mathrm{l}$ of solution C1 (step 2), the samples were incubated at $65^{\circ} \mathrm{C}$ for $20 \mathrm{~min}$ to inactivate the DNases (Marotz et al. 2017). Samples were then vortexed for $20 \mathrm{~min}$ (step 4) and incubated at $4^{\circ} \mathrm{C}$ (step 7). In step 9 of the protocol, only $600 \mu \mathrm{l}$ of supernatant was used, with $200 \mu \mathrm{l}$ of C3 in step 10. All DNA samples were quantified using a Nanodrop 2000C spectrophotometer (Thermo Scientific, Waltham, MA, U.S.A.). Extracted DNA was visualized on a $1 \%$ agarose gel (Invitrogen Ultrapure catalog number 16500-500) in 0.5× Tris-borate-EDTA buffer. PCR amplification was carried out with the same primer pairs that were used for subsequent metaamplicon sequencing to ensure that the DNA was of good quality.

A negative control was employed for the DNA-extraction step. PCR was performed on the negative control and samples with the same primers used for sequencing. Because no amplification was observed in the negative control, it was not sent for sequencing.

For sequencing, $20 \mu \mathrm{l}$ of the extracted DNA sample was sent to the Dalhousie University CGEB-IMR lab (https://imr.bio). The V6-V8 region of the $16 \mathrm{~S}$ ribosomal RNA (rRNA) gene (16S) with bacteria-specific primers B969F (ACGCGHNRAACCTTACC) and BA1406R (ACGGGCRGTGWGTRCAA) and for fungi internal transcribed spacer (ITS) region 2 ribosomal DNA gene (ITS2) with primers ITS86F (GTGAATCATCGAATCTTTGAA) and ITS4 (TCCTCCGCTTATTGATATGC) were used for library preparation and sequencing. The universal ITS2 primers capture a wide range of fungal diversity, including AMF (Berruti et al. 2017; Morgan et al. 2017; Schoch et al. 2012). Samples were multiplexed using a dual-indexing approach and sequenced using an Illumina MiSeq platform with paired-end $300+300$-bp reads. All PCR procedures and Illumina sequencing details were as described by Comeau et al. (2017). Raw sequencing data are publicly posted on the European Nucleotide Archive (PRJEB45622).

Soil statistical analyses. An analysis of variance (ANOVA) was used to analyze the data in instances where the assumptions of constant variance and a normal distribution of the error term were not violated. In instances where one or both of these assumptions were violated, a transformation was used. These statistical analyses were carried out in $\mathrm{R}$ version 3.5.3 ( $\mathrm{R}$ Core Team 2019).

Bioinformatics statistical analysis. Raw amplicon-sequencing reads were first inspected using FASTQC (v0.11.4; https://www. bioinformatics.babraham.ac.uk/projects/fastqc). Primer sequences were then trimmed from the reads using cutadapt v1.11 (Martin 2011). These trimmed reads were then processed with QIIME 2 version 2018. 8 (Bolyen et al. 2019) to run several key steps. First, DADA2 v1.6.0 (Callahan et al. 2016) was run to stitch together forward and reverse reads; then, read error models were determined; and final amplicon sequence variants (ASVs) were output using the following options: p-trunc-len-f 270, p-trunc-len-r 210, and p-max-ee 3. ASVs with a frequency $<0.1 \%$ of the total reads for the $16 \mathrm{~S}$ and ITS datasets were filtered out. This resulted in the exclusion of reads below a threshold of 37 and 7 for the 16S and ITS datasets, respectively. ASVs were aligned with MAFFT v7.310 (Katoh and Standley 2013) to create de novo multiple sequence alignments, which were used to create a tree using FastTree v2.1.10 (Price et al. 2010). Taxonomic classification of the $16 \mathrm{~S}$ ASVs was performed with a Naïve-Bayes classifier against the SILVA 16S database v132 (Quast et al. 2013) restricted to the V6-V8 region. The ITS ASVs were classified using the same method against the UNITE ITS database v7.2 (Nilsson et al. 2019). All ASVs were classified successfully except for 46 ITS ASVs. Seven ASVs classified as chloroplast and three ASVs classified as mitochondria were removed. These ASVs corresponded to a mean of $0.569 \%$ of the relative abundance (RA) per sample (standard deviation $=0.587 \%$ ). The QIIME 2 command "diversity core-metrics-phylogenetic" was then used to output the default $\alpha$ - and $\beta$-diversity metrics with a p-sampling-depth threshold of 4,000.

In addition to running DADA2, deblur was also run to generate ITS-based ASVs (Amir et al. 2017). We did this to investigate how the choice of denoising method impacted the inferred presence of Glomeromycota. To run deblur, forward and reverse reads were paired with VSEARCH and then quality filtered with the qualityfilter q-score-joined command (Rognes et al. 2016). These steps were run in QIIME 2 with default options. Deblur was also run in QIIME 2 with default options, with the exceptions of not filtering out ASVs based on depth and a trim length of $263 \mathrm{bp}$. This trim length represented the bottom $2 \%$ of all sequences in the deblur pipeline. We selected this cut-off to be conservative in order to not miss potential Glomeromycota sequences.

All bioinformatic statistical analyses were conducted using QIIME2 and in R (3.6.0; https://www.R-project.org/). The CCAs were generated with the vegan $R$ package (version 2.5-4). An Adonis test (permutational multivariate analysis of variance [PERMANOVA]) was used to see to what degree the variance was explained by different factors; Bray-Curtis, unweighted principal coordinate analysis (PCoA), and weighted PCoA methods were used, permutations $=9,999$ in the vegan package in $\mathrm{R}$ using the formula (distance matrix) approximately rootstock + root depth + vine + rootstock $\times$ root depth. A separate Adonis test (PERMANOVA), based on Bray-Curtis dissimilarity, was used to determine what proportion of the variance in the taxonomic composition was explained by sample type (grape root, cover crop root, and soil). Spearman's correlations used multiple testing corrections within a particular diversity metric. Differential abundance testing of genera was performed using ALDEx2 version 1.24.0 (Fernandes et al. 2013); significant results were based on Benjamini-Hochberg corrected values for the Kruskal-Wallis test.

We have made our key code and datafiles available at this GitHub repository: https://github.com/zoemigicovsky/cool_climate_ grape_microbiome.

\section{RESULTS}

Microbiome and sample type (cover crop root, grape root, and soil). A breakdown of the resolved taxa, from phylum to species, for the cover crop root, grape root, and soil can be found in Supplementary Files S1, S2, and S3, respectively. Rarefaction curves for both bacteria and fungi for all samples can be found in Supplementary Figure S1. All grape root, cover crop root, and bulk soil samples produced usable $16 \mathrm{~S}$ sequences. However, for the ITS sequences, although $100 \%$ of the cover crop root and bulk soil samples produced usable reads, $41 \%$ of the grape-root samples failed to sequence and were excluded from the analyses. For bacteria, the 
soil, grape root, and cover crop root were dominated by Proteobacteria (30, 68, and 50\%, respectively) followed by Bacteroidetes (18, 14, and 36\%, respectively). Actinobacteria and Firmicutes were the next most dominant bacteria phyla for the grape and cover-crop roots, while Acidobacteria (18\%) was next for the soil and was greatly overrepresented compared with the roots. At the species level, Bacillus simplex and Rhizobium leguminosaurus were overrepresented in the grape roots compared with the soil and the cover crop roots, and Agrobacterium radiobacter, Paenibacillus amylolyticus, and plant Pantoea agglomerans were detected only in grape root but not in soil samples. In terms of fungi, the soil, grape root, and cover crop were all dominated by Ascomycota (59, 80, and 63\%, respectively); Basidiomycota was the second-most abundant phylum for the grape and cover-crop roots (18 and 32\%, respectively), while Mortierellomycota was the second most common phylum in the soil, followed by Basidiomycota (19 and 17\%, respectively). Meaningfully, Glomeromycota figured prominently in the cover crop roots $(67 \%$ prevalence and 3\% RA) and was present in the soil (11\% prevalence and $\mathrm{RA}=0.02 \%$ ), but was not detected in the grape roots after filtering out rare ASVs from the DADA2 results (Supplementary Files S1, S2, S3, and S4). Interestingly, if unfiltered DADA2 or deblur were instead used as the denoising algorithm, Glomeromycota was identified as part of the grape-root microbiome, as a minor component. Both unfiltered DADA2 and deblur results indicated Glomeromycota were present in $30 \%$ of the grape-root samples, with deblur results indicating a RA of $1.9 \%$ (Supplementary File S4).

An Adonis test (PERMANOVA), based on Bray-Curtis dissimilarity, showed significant differences in the taxonomic composition between the root (grape and cover crop) and soil communities for both bacteria $\left(R^{2}=0.33, P<0.001\right)$ and fungi $\left(R^{2}=0.40, P<\right.$ $0.001)$. Similarly, significant differences in the bacterial $\left(R^{2}=0.28\right.$, $P<0.001)$ and fungal $\left(R^{2}=0.29, P<0.001\right)$ communities were also observed between the grape roots and the roots of the fescue cover crop. The $\alpha$-diversity indices (observed ASVs, evenness, and Shannon index) were all highest in the soil and lowest in the grape roots for the bacteria; the same was true for the fungi, with the exception of evenness, which was lowest in the cover-crop roots (Table 1). The bacterial community showed greater overlap ( $>40 \%)$ in the genera involved between all three sample types (grape root, soil, and cover crop) compared with the fungal community $(<20 \%)$ (Fig. 1A and B; Table 1). For both the bacterial and fungal communities, the greatest proportion of specialists was found in the grape soil, while a lower fraction of specialists was observed in the roots of the grapevines and the cover crop (Fig. 1A and B). The top 15 genera across all three sample types can be found in Figure 1C and D. The top 15 classified bacteria and fungi genera found in the grape root systems alone, as well as their known associations as found in the literature, can be found in Tables 2 and 3, respectively.

Grape microbiome, soil parameters, and root phenotypes. The soil properties associated with each vine consisted of the $\mathrm{pH}$, organic matter (\%), and cation exchange capacity (CEC), as well as a range of macronutrients and micronutrients $\left(\mathrm{P}_{2} \mathrm{O}_{5}, \mathrm{~K}_{2} \mathrm{O}, \mathrm{Ca}, \mathrm{Mg}\right.$, $\mathrm{Na}, \mathrm{S}, \mathrm{Al}, \mathrm{B}, \mathrm{Cu}, \mathrm{Fe}, \mathrm{Mn}$, and Zn) (Table 4). When a Spearman's correlation was performed between microbiome richness, evenness, and Shannon's phylogenetic diversity and the various soil parameters, no soil parameters were found to be correlated with these $\alpha$-diversity metrics for either bacteria or fungi. When the same analysis was performed between the soil parameters measured and the top 10 fungi and bacteria features, BenjaminiHochberg-corrected results suggested that there was little correlation between the two, with one exception: the fungi genus Pseudaleuria was found to be positively correlated with $\mathrm{Na}\left(r^{2}=\right.$ $0.54, P=0.02)$ and $\mathrm{Mn}\left(r^{2}=0.56, P=0.02\right)$ levels and negatively correlated with Fe levels $\left(r^{2}=0.50, P=0.03\right)$. A Spearman's correlation showed there was no significant correlation between root phenotype (trunk diameter, secondary root mass, tertiary root mass, and total root mass) and $\alpha$-diversity metrics (evenness, richness, and Shannon's phylogenetic diversity) for bacteria. However, evenness was found to be positively correlated with total root mass for the fungi $\left(r^{2}=0.34, P=0.02\right)$.

Grape root microbiome across soil depth (0 to 15, 15 to 30, and 30 to $50 \mathrm{~cm})$. A breakdown of the resolved taxa, from phylum to species for the soil depths of 0 to 15,15 to 30 , and 30 to $50 \mathrm{~cm}$ can be found in Supplementary Files S5, S6, and 7, respectively. The results of the soil analyses showed that the different soil depths offered distinct microenvironments (Supplementary Table S1). The soil $\mathrm{pH}$, organic matter, and CEC were all highest in the uppermost soil level. Absolute levels of phosphorous,

TABLE 1

Observed amplicon sequence variants (ASVs), evenness, and Shannon index for both 16S (bacteria) and internal transcribed spacer (ITS) (fungi) across vineyard substrate, root types, and depths ${ }^{\mathrm{z}}$

\begin{tabular}{|c|c|c|c|c|c|c|}
\hline \multirow[b]{2}{*}{ Niche } & \multicolumn{2}{|c|}{ Observed ASVs } & \multicolumn{2}{|c|}{ Evenness } & \multicolumn{2}{|c|}{ Shannon } \\
\hline & $16 S$ & ITS & $16 S$ & ITS & $16 S$ & ITS \\
\hline \multicolumn{7}{|l|}{ Sample type } \\
\hline Grape root & $436 \pm 156 \mathrm{~B}$ & $37 \pm 16 \mathrm{C}$ & $0.81 \pm 0.07 \mathrm{~B}$ & $0.62 \pm 0.05 \mathrm{AB}$ & $7.01 \pm 0.94 \mathrm{~B}$ & $3.21 \pm 0.30 \mathrm{~B}$ \\
\hline Cover crop root & $690 \pm 109 A$ & $57 \pm 19 B$ & $0.90 \pm 0.02 \mathrm{~A}$ & $0.58 \pm 0.18 \mathrm{~B}$ & $8.43 \pm 0.38 \mathrm{~A}$ & $3.40 \pm 1.30 \mathrm{~B}$ \\
\hline $3309 \mathrm{C}$ & $448 \pm 124 \mathrm{~A}$ & $39 \pm 15.7 \mathrm{~A}$ & $0.80 \pm 0.05 \mathrm{~A}$ & $0.63 \pm 0.05 \mathrm{~A}$ & $7.00 \pm 0.71 \mathrm{~A}$ & $3.23 \pm 0.30 \mathrm{~A}$ \\
\hline Riparia Gloire & $365 \pm 125 \mathrm{~A}$ & $37 \pm 7.9 \mathrm{~A}$ & $0.79 \pm 0.06 \mathrm{~A}$ & $0.60 \pm 0.08 \mathrm{~A}$ & $6.61 \pm 0.85 \mathrm{~A}$ & $3.12 \pm 0.49 \mathrm{~A}$ \\
\hline \multicolumn{7}{|l|}{ Grape root depth } \\
\hline 0 to $15 \mathrm{~cm}$ & $392 \pm 148 \mathrm{~A}$ & $36 \pm 9.0 \mathrm{~A}$ & $0.79 \pm 0.05 \mathrm{~A}$ & $0.65 \pm 0.01 \mathrm{~A}$ & $6.69 \pm 0.81 \mathrm{~A}$ & $3.29 \pm 0.25 \mathrm{~A}$ \\
\hline
\end{tabular}

${ }^{\mathrm{z}}$ Averages, followed by standard deviation, with like letter groupings within a column for a given category are not significantly different according to Tukey's pairwise test $(P<0.05)$. 
potassium, calcium, magnesium, boron, copper, iron and zinc, and base saturation $\mathrm{K} \%$ and $\mathrm{Ca} \%$ were, likewise, found at their highest levels in the uppermost soil level. The base saturation $\mathrm{Na} \%$ and $\mathrm{Mg} \%$ levels were the only two nutrient parameters found to be highest in the lowest soil level (Supplementary Table S1).

Significant overlap in the genera was found in both the bacteria $(>65 \%)$ and the fungi ( $>30 \%$ ) across soil depths (Fig. 2A and B). An Adonis Test (PERMANOVA) showed that root depth did explain a portion of the variance of the taxonomic composition for the bacterial $\left(16 \mathrm{~S} ; r^{2}=0.09, P<0.01\right)$, but not for the fungal (ITS; $r^{2}=0.12$ ) communities (Table 4). In particular, the Firmicutes bacteria was a prominent phylum represented in the shallowest depth (0 to $15 \mathrm{~cm}$ ), with an RA of $3 \%$, but was less prominent at the deeper soil depths, where the RA was $<1 \%$ (Supplementary Files S5, S6, and S7). An ALDEx2 analysis combined with a glm

\section{A Bacteria}

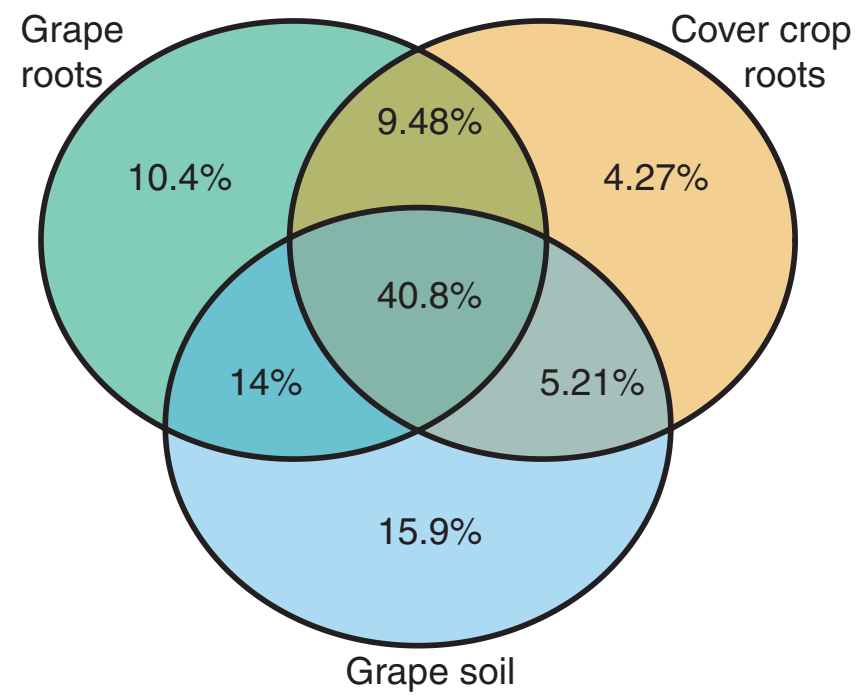

\section{Bacteria}

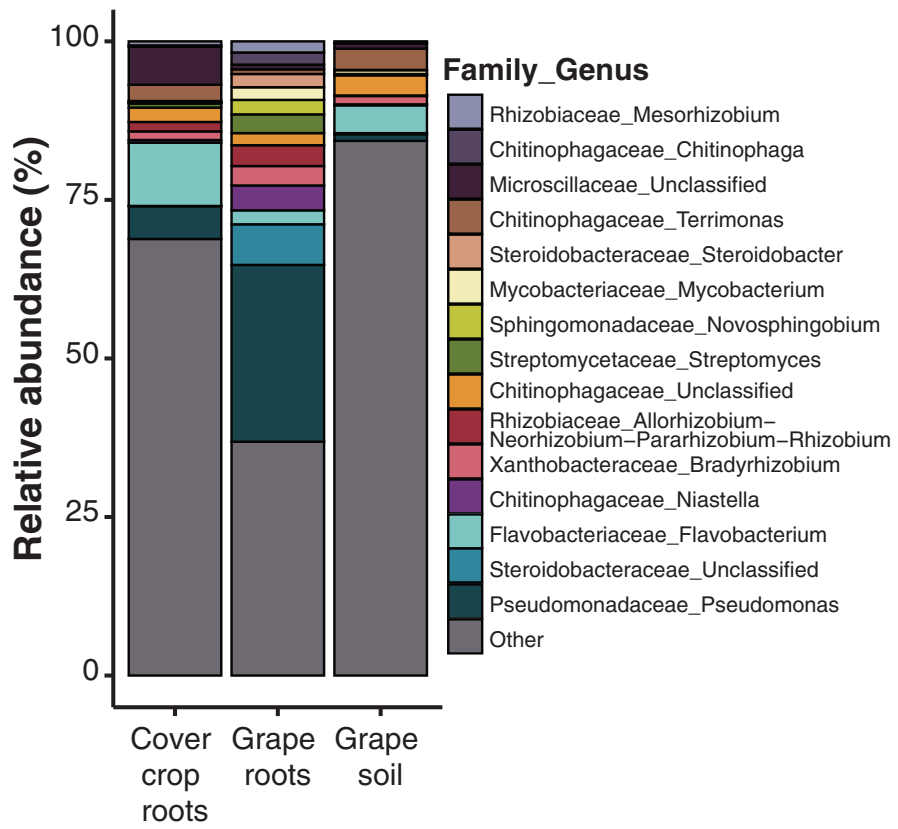

ANOVA showed that no bacterial or fungal genera had a depthspecific effect. $\alpha$-Diversity indices from grape roots sampled from the three depths showed no differences (Table 1).

$\alpha$ Diversity from bulk soil samples did not reveal strong trends along the soil column. The exception was fungal evenness: plotting the values suggested that evenness was greater at the deepest soil level sampled $(30$ to $50 \mathrm{~cm})$ relative to the shallowest $(0$ to $15 \mathrm{~cm})$ (Supplementary Fig. S2).

Grape root microbiome across root type (ungrafted, 3309C, and Riparia Gloire). A breakdown of the resolved taxa, from phylum to species, for the ungrafted, 3309C, and Riparia Gloire grape root types can be found in Supplementary Files S8, S9, and S10, respectively. There was greater overlap in the genera observed across root type in the bacteria relative to the fungi genera (Fig. 3). With regards to specialization across grape rootstock types, 3309C

\section{B Fungi}

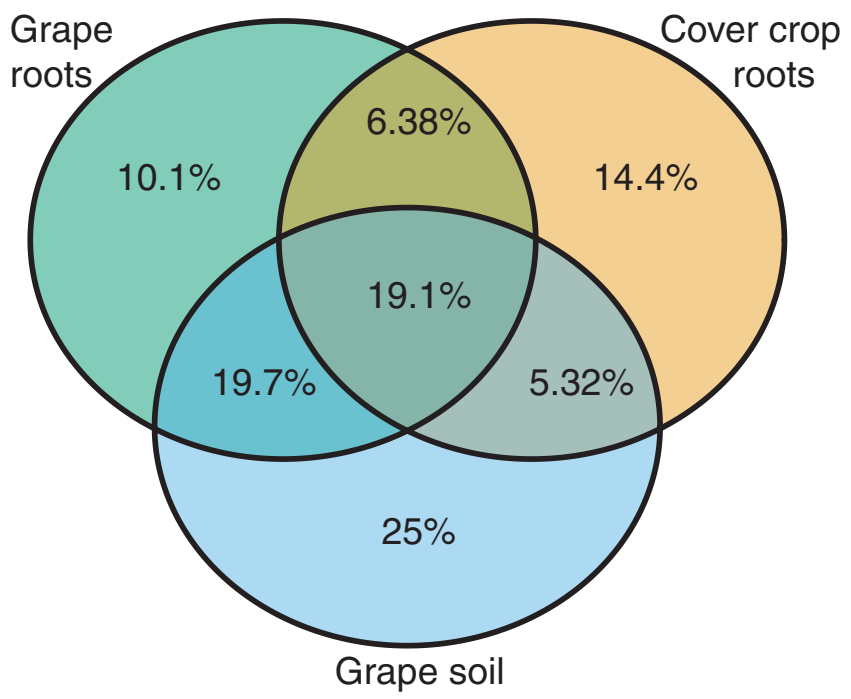

\section{Fungi}

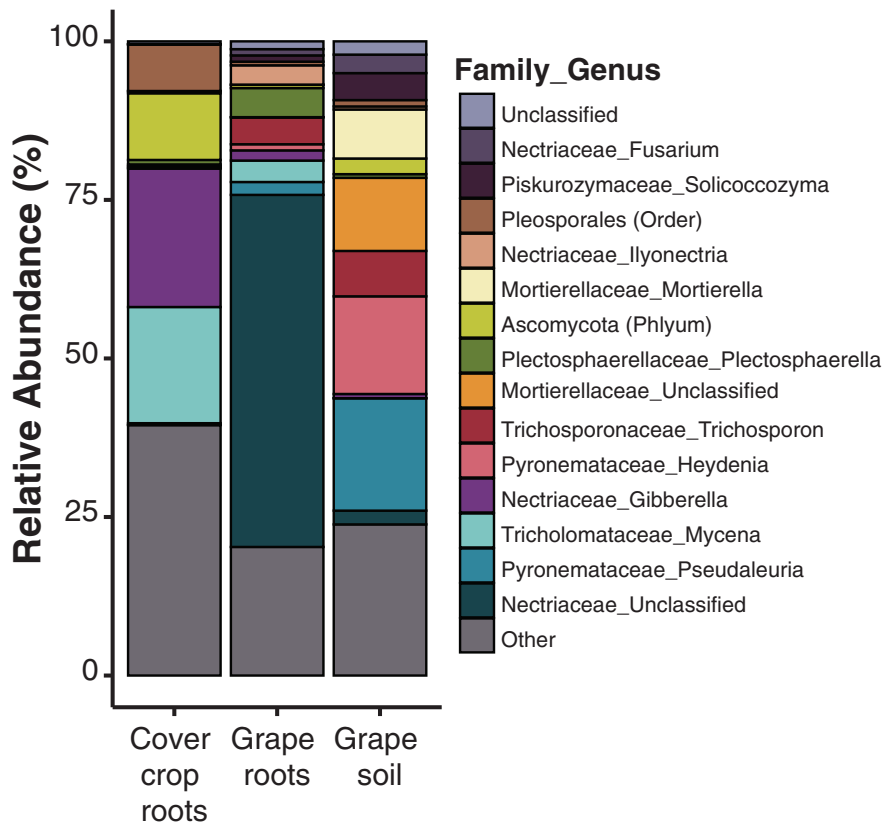

Fig. 1. Venn diagrams showing the overlap in A, bacterial and $\mathbf{B}$, fungal genera found between the grape roots, soil, and cover crop roots and the top 15 most abundant $\mathbf{C}$, bacteria and $\mathbf{D}$, fungi genera found in the same. 
TABLE 2

Top 15 classified bacteria genera detected in grapevine roots using $16 \mathrm{~S}$ (V6-V8) metaamplicon barcoding ${ }^{2}$

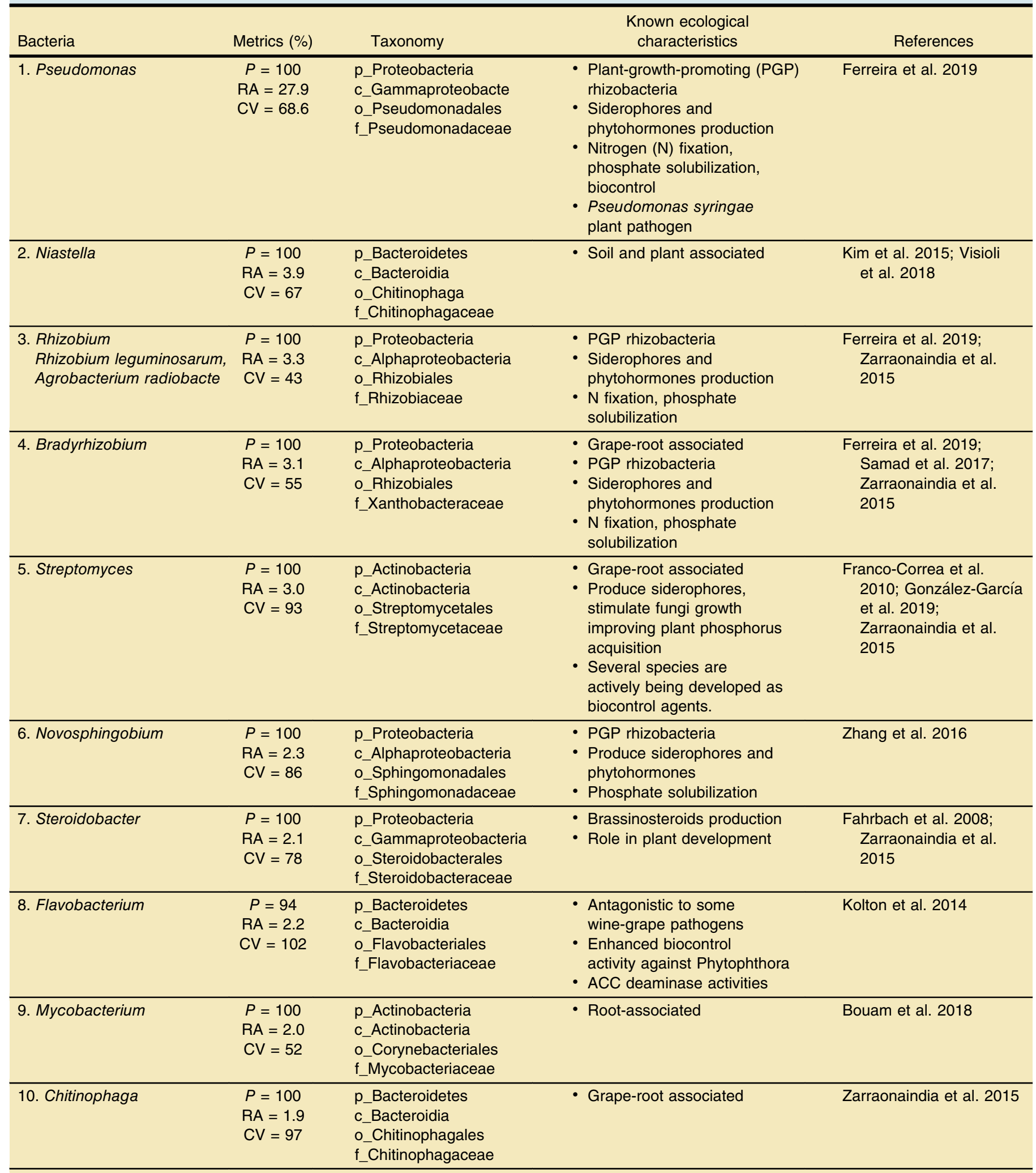

(Continued on next page)

${ }^{z}$ Genera are ranked according to the product of their prevalence $(P)$ multiplied by their mean relative abundance (RA) in grapevine root samples; the coefficient of variation (CV) is also shown. Species names are listed under genus if classified and found to be present in relatively high abundances. 


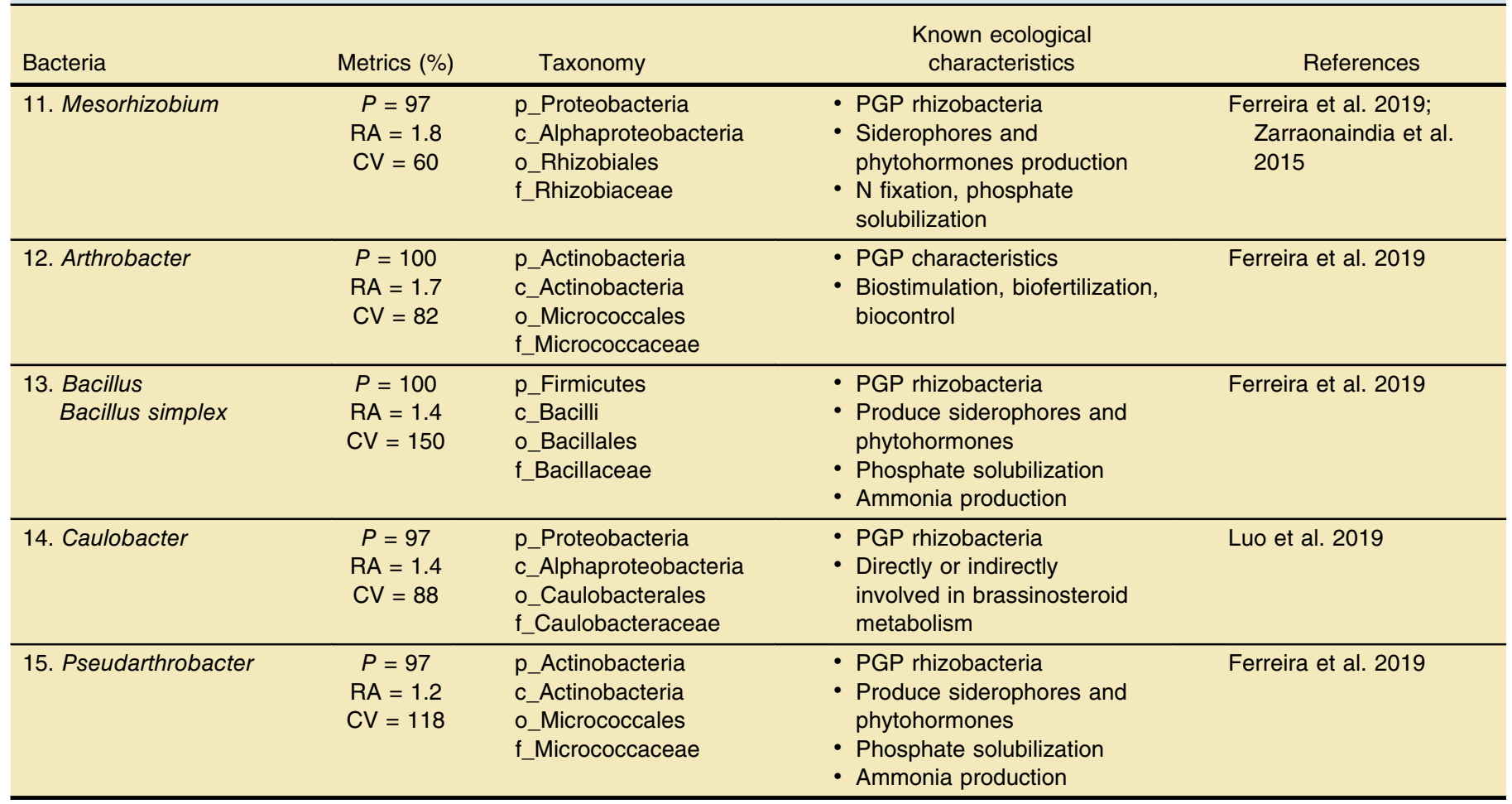

had the most unique genera for bacteria, while Riparia Gloire had the most unique fungal genera (Fig. 3A and B). An Adonis Test (PERMANOVA) showed that grape rootstock did explain a portion of the variance of the taxonomic composition for both the bacterial $\left(16 \mathrm{~S} ; r^{2}=0.13, P<0.001\right)$ and fungal (ITS; $r^{2}=0.22, P<0.01$ ) communities, although the explanatory power of this factor was low (Table 4) and there were no differences in $\alpha$ diversity indices (Table 1). An ALDEx2 analysis combined with a glm ANOVA showed that no fungal genera had a significant root type-specific effect; however, root type was found to have a significant effect for 12 bacterial genera $(P<0.05)$. The relationships between root type and these bacterial genera can be found in Supplementary Figure S3.

The average root mass found in the excavated area for the ownrooted, Riparia Gloire, and 3309C vines was 400, 142, and $258 \mathrm{~g}$, respectively. An ANOVA followed by a Tukey multiples means comparison showed that these values were all significantly different from one another. An analysis of soil parameters across the individual vines, as broken down by root type, showed some differences between root type sites; in particular, organic matter (\%), CEC, $\mathrm{P}_{2} \mathrm{O}_{5}, \mathrm{~K}_{2} \mathrm{O}$, Na, and $\mathrm{Cu}$ levels all showed higher values for the own rooted vines compared with Riparia Gloire and 3309C (Supplementary Table S2).

\section{DISCUSSION}

Plant microbial specialization. The source material (soil versus root tissue) had the strongest effect on bacterial and fungal microbiome structure and had the most explanatory power among all factors tested. Microbial diversity was greater in soil than in plant roots for both fungi and bacteria (Table 1). This agrees with other agri-plant systems and is explained by a demand for microbial specialization necessary for invasion and survival inside plant tissue (Hacquard et al. 2015; Lundberg et al. 2012; Vandenkoornhuyse et al. 2015; Yurgel et al. 2018). Host plants actively recruit soil PGP microorganisms by secreting root-derived chemoattractants (Babalola et al. 2020; Bulgarelli et al. 2013; Pascale et al. 2020).
Plant species (cover crop versus grape) was the second-strongest factor affecting the structure of the root microbiome. The bacterial grape-root microbiome exhibited lower $\alpha$ diversity than the covercrop microbiome, which was reflected as a decrease in the microbiome evenness, Shannon index, and observed ASVs, suggesting stronger plant selective pressure by the grape root compared with the cover crop. The effect was not as great in the grape-root fungal microbiome, which was far less rich than the bacteria. However, what was consistent was that the number of observed fungal ASVs in the grape roots was lower than that observed in the cover crop (Table 1). It should be noted that the location of the fescue grass, in the untilled aisleway, and that of the grape, which was in the row, cannot be disentangled from the plant species in this study. To our knowledge, this study is unique in that it compares the microbiome of the grape roots to that of the dominant cover crop, a fescue grass.

Present study's vineyard microbiome as compared with past studies. Because this is the first root microbiome study of a Canadian vineyard, we provide valuable biodiversity data for comparison with other global vineyards, as well as to future studies in our region.

Two previous studies in a Mediterranean climate used universal ITS primers to look at the fungal microbiome in grape (Berlanas et al. 2019; Martínez-Diz et al. 2019). All of the fungal taxa that were identified in this study within grapevine roots were previously identified by different groups (Marzano et al. 2016; Mezzasalma et al. 2018; Miura et al. 2017; Morgan et al. 2017; Portillo et al. 2016; Salvetti et al. 2016; Zarraonaindia et al. 2015).

Ascomycete and Basidiomycete fungi dominated both soil and root fungal assemblages similar to other recent studies (Berlanas et al. 2019; Martínez-Diz et al. 2019; Swift et al. 2021). The second most dominant phylum in our rhizosphere soil, however, was Mortierellomycota, followed by Basidiomycota, which differs from these previous studies. Mortierellomycota has only recently been classified as a unique phylum, which may explain this difference (Tedersoo et al. 2018). The grapevine root samples in the present study may be further classified as being dominated by unidentified 
TABLE 3

Top 15 classified fungi genera detected in grapevine roots using internal transcribed spacer 2 metaamplicon barcoding ${ }^{2}$

\begin{tabular}{|c|c|c|c|c|}
\hline Fungi & Metrics (\%) & Taxonomy & $\begin{array}{l}\text { Known ecological } \\
\text { characteristics }\end{array}$ & References \\
\hline 1. Trichosporon & $\begin{array}{l}P=100 \\
R A=4.3 \\
C V=99\end{array}$ & $\begin{array}{l}\text { p_Basidiomycota } \\
\text { c_Tremellomycetes } \\
\text { o_Trichosporonales } \\
\text { f_Trichosporonaceae }\end{array}$ & $\begin{array}{l}\text { - Approximately } 50 \text { species } \\
\text { currently in this genus } \\
\text { - Most often soil-dwelling } \\
\text { - May be present on } \\
\text { grapevines }\end{array}$ & $\begin{array}{l}\text { Barata et al. 2012; } \\
\text { Comitini and Ciani } \\
\text { 2008; Moll et al. 2016; } \\
\text { Yurkov } 2018\end{array}$ \\
\hline $\begin{array}{l}\text { 2. Plectosphaerella } \\
\text { Plectosphaerella } \\
\text { cucumerina (formerly } \\
\text { Fusarium tabacinum), } \\
\text { Microdochium } \\
\text { tabacinum, } \\
\text { Monographella } \\
\text { cucumerina) }\end{array}$ & $\begin{array}{l}P=90 \\
\mathrm{RA}=4.6 \\
\mathrm{CV}=107\end{array}$ & $\begin{array}{l}\text { p_Ascomycota } \\
\text { c_Sordariomycetes } \\
\text { o_Glomerellales } \\
\text { f_Plectosphaerellaceae }\end{array}$ & $\begin{array}{l}\text { Soil saprobe, notable plant } \\
\text { pathogen (necrotrophic), } \\
\text { pathogen } \\
\text { of nematodes }\end{array}$ & Ramos et al. 2013 \\
\hline 4. Mycena & $\begin{array}{l}P=40 \\
R A=3.4 \\
C V=239\end{array}$ & $\begin{array}{l}\text { p_Basidiomycota } \\
\text { c_Agaricomycetes } \\
\text { o_Agaricales } \\
\text { f_Tricholomataceae }\end{array}$ & $\begin{array}{l}\text { - Mainly found in roots of } \\
\text { green plants } \\
\text { - Cycles carbon and } \\
\text { nitrogen } \\
\text { - Some species use } \\
\text { formaldehyde as a chemical } \\
\text { defense of fruiting bodies }\end{array}$ & $\begin{array}{l}\text { Grelet et al. 2017; } \\
\text { Himstedt et al. } 2020 ; \\
\text { Thoen et al. } 2020\end{array}$ \\
\hline $\begin{array}{l}\text { 6. Fusarium } \\
\text { Fusarium oxysporum, } \\
\text { F. tricinctum (formerly } \\
\text { G. tricincta), F. solani }\end{array}$ & $\begin{array}{l}P=95 \\
R A=1.0 \\
C V=69\end{array}$ & $\begin{array}{l}\text { p_Ascomycota } \\
\text { c_Sordariomycetes } \\
\text { o_Hypocreales } \\
\text { f_Nectriaceae }\end{array}$ & $\begin{array}{l}\text { - Most Fusarium spp. are } \\
\text { saprobes; many notable } \\
\text { plant pathogens are in this } \\
\text { genus. } \\
\text { F. tricictum causes head } \\
\text { blight in cereal grains. } \\
\text { F. solani causes disease } \\
\text { in pea, cucurbits and sweet } \\
\text { potato, among other crop } \\
\text { plants. }\end{array}$ & $\begin{array}{l}\text { Bottalico and Perrone } \\
\text { 2002; Lombard et al. } \\
\text { 2015; Nelson et al. } \\
\text { 1994; O'Donnell } 2000\end{array}$ \\
\hline 7. Cadophora & $\begin{array}{l}P=85 \\
R A=1.0 \\
C V=61\end{array}$ & $\begin{array}{l}\text { P_Ascomycota } \\
\text { c_Leotiomycetes } \\
\text { o_Helotiales } \\
\text { f_Helotiales_fam_ } \\
\text { Incertae_sedi }\end{array}$ & $\begin{array}{l}\text { Cadophora luteo-olivacea, } \\
\text { most prevalent species } \\
\text { associated with diseased } \\
\text { vines in Canada } \\
\text { - Associated with Petri } \\
\text { disease and Esca }\end{array}$ & $\begin{array}{l}\text { Maldonado-González } \\
\text { et al. } 2020\end{array}$ \\
\hline
\end{tabular}

(Continued on next page)

\footnotetext{
${ }^{z}$ Genera are ranked according to the product of their prevalence $(P)$ multiplied by their mean relative abundance (RA) in grapevine root samples; the coefficient of variation (CV) is also shown. Species names are listed under genus if classified and found to be present in relatively high abundances.
} 


\begin{tabular}{|c|c|c|c|c|}
\hline Fungi & Metrics (\%) & Taxonomy & $\begin{array}{l}\text { Known ecological } \\
\text { characteristics }\end{array}$ & References \\
\hline 8. Tetracladium & $\begin{array}{l}P=65 \\
R A=1.1 \\
C V=179\end{array}$ & $\begin{array}{l}\text { p_Ascomycota } \\
\text { c_Leotiomycetes } \\
\text { o__Helotiales } \\
\text { f_Helotiaceae }\end{array}$ & $\begin{array}{l}\text { - Plant growth promoter } \\
\text { - Found in vineyards } \\
\text { - An endophyte that helps } \\
\text { degrade plant debris }\end{array}$ & $\begin{array}{l}\text { Chen et al. 2020; Liang } \\
\text { et al. 2019; Wei et al. } \\
2018\end{array}$ \\
\hline $\begin{array}{l}\text { 9. Solicoccozyma } \\
\text { Solicoccozyma terrea, } \\
\text { S. terricola (formerly } \\
\text { Cryptococcus terreus, } \\
\text { C. terricola) }\end{array}$ & $\begin{array}{l}P=75 \\
\mathrm{RA}=1.0 \\
\mathrm{CV}=114\end{array}$ & $\begin{array}{l}\text { p_Basidiomycota } \\
\text { c_Tremellomycetes } \\
\text { O_Filobasidiales } \\
\text { f_Piskurozymaceae }\end{array}$ & $\begin{array}{l}\text { - Present in soils and leaf } \\
\text { litter } \\
\text { - Isolated from vineyards } \\
\text { - S.terricola is a } \\
\text { psychotolerant yeast }\end{array}$ & $\begin{array}{c}\text { Bougreau et al. } 2019 \\
\text { Stosiek et al. } 2019\end{array}$ \\
\hline $\begin{array}{l}\text { 10. Naganishia } \\
\text { Naganishia albida, } \\
\text { N. randhawae }\end{array}$ & $\begin{array}{l}P=55 \\
R A=1.1 \\
C V=263\end{array}$ & $\begin{array}{l}\text { p_Basidiomycota } \\
\text { c_Tremellomycetes } \\
\text { o_ Filobasidiales } \\
\text { f_Biolbasidiaceae }\end{array}$ & $\begin{array}{l}\text { - A yeast } \\
\text { - Isolated from withered } \\
\text { grape berries } \\
\text { - Resistant to UV, } \\
\text { psychrotolerant and } \\
\text { halotolerant }\end{array}$ & $\begin{array}{l}\text { Lorenzini and Zapparoli } \\
\text { 2019; Schmidt et al. } \\
2017\end{array}$ \\
\hline $\begin{array}{l}\text { 12. Clonostachys } \\
\text { Clonostachys rosea }\end{array}$ & $\begin{array}{l}P=85 \\
\mathrm{RA}=0.7 \\
\mathrm{CV}=96\end{array}$ & $\begin{array}{l}\text { p_Ascomycota } \\
\text { c_Sordariomycetes } \\
\text { O_Hypocreales } \\
\text { f_Bionectriaceae }\end{array}$ & $\begin{array}{l}\text { - Common in soils. Found in } \\
\text { plants as endophytes, } \\
\text { epiphytes, and saprotrophs. } \\
\text { - A mycoparasitic fungus, } \\
\text { usually a biocontrol for plant } \\
\text { pathogens or as a facultative } \\
\text { pathogens of nematodes } \\
\text { - C. rosea proliferates better } \\
\text { in disturbed and } \\
\text { conventionally cultivated } \\
\text { habitats. }\end{array}$ & $\begin{array}{l}\text { Moloinyane et al. } 2020 \\
\text { Torcato et al. } 2020\end{array}$ \\
\hline 13. Alternaria & $\begin{array}{l}P=65 \\
R A=0.8 \\
C V=303\end{array}$ & $\begin{array}{l}\text { P_Ascomycota } \\
\text { c_Dothideomycetes } \\
\text { O_Pleosporales } \\
\text { f_Pleosporaceae }\end{array}$ & $\begin{array}{l}\text { - Alternaria is a ubiquitous } \\
\text { genus isolated from most } \\
\text { environments, most often } \\
\text { saprobes. } \\
\text { - Common plant pathogens in } \\
\text { many crop plants } \\
\text { - Alternaria is associated } \\
\text { with grape bunch rot and } \\
\text { passito style wines. }\end{array}$ & $\begin{array}{l}\text { Lorenzini and Zapparoli } \\
\text { 2014; Woudenberg } \\
\text { et al. } 2013\end{array}$ \\
\hline $\begin{array}{l}\text { 14. Heydenia } \\
\text { Heydenia alpina }\end{array}$ & $\begin{array}{l}P=45 \\
R A=1.0 \\
C V=295\end{array}$ & $\begin{array}{l}\text { p_Ascomycota } \\
\text { c_Pezizomycetes } \\
\text { o_Pezizales } \\
\text { f_Pyronemataceae }\end{array}$ & $\begin{array}{l}\text { - Plant saprobe } \\
\text { - Few records; one record of } \\
\text { isolation from vineyard soil in } \\
\text { the Badacsony wine region } \\
\text { of Hungary }\end{array}$ & $\begin{array}{r}\text { Geröcs et al. 2016; } \\
\text { Leuchtmann and } \\
\text { Clémençon } 2012\end{array}$ \\
\hline $\begin{array}{l}\text { 15. Filobasidium } \\
\text { Filobasidium } \\
\text { globisporum, } \\
\text { F. magnum }\end{array}$ & $\begin{array}{l}P=45 \\
R A=0.9 \\
C V=200\end{array}$ & $\begin{array}{l}\text { p_Basidiomycota } \\
\text { c_Tremellomycetes } \\
\text { o_Filobasidiales } \\
\text { f_Filobasidiaceae }\end{array}$ & $\begin{array}{l}\text { Yeasts commonly } \\
\text { epiphytic populations from } \\
\text { grapevines (leaf, sap, berry/ } \\
\text { fruit samples rather than soil) }\end{array}$ & Bougreau et al. 2019 \\
\hline
\end{tabular}

fungal genera within the family Nectriaceae. However, based on fungi commonly isolated in soil and plant root microbiomes, likely genera include Bionectria, Calonectria, Cylindrocarpon/Neonectria, Fusarium/Gibberella, and Ilyonectria (Bonito et al. 2014, 2016; Chapelle et al. 2016; Toju et al. 2018). Other Nectriaceae genera of interest to viticulture are Camplyocarpon, Cylindrocladiella, Dactylonectria, and Thelonectria; along with members of Ilyonectria and Cylindrocarpon/Neonectria, species of these genera cause black foot rot in grapevine (Agustí-Brisach and Armengol 2013; Gramaje et al. 2018; Úrbez-Torres et al. 2014). Grapevine root samples also 
contained consistent abundances of two Nectriaceae genera that were definitively resolved: Fusarium and Ilyonectria. Other fungi present across grapevine root samples in relatively high abundances include Mycena, Pseudaleuria, Plectosphaerella, and Trichosporon spp. and unclassified members of Pleosporales. The cover-crop roots consist of the largest proportion of "other" fungal genera (genera that do not rank within the 15 most abundant among all samples). Genera of notable abundance in the cover crop root samples were Gibberella, Mycena, and unclassified members of Pleosporales. When comparing the most abundant fungi we documented in grape roots with taxa documented in other vineyard studies, three fungi stand out. Clonostachys sp. was the 12th most abundant fungus observed from grape roots during our study. In other recent studies, the abundance of Clonostachys rosea has determined the dissimilarity of fungal assemblages between the rootstock genotypes and between rhizosphere and bulk soil types (Berlanas et al. 2019; Martínez-Diz et al. 2019). Ilyonectria sp. was the third most abundant species from grape roots in our study, and determined the dissimilarity of fungal assemblages between rhizosphere and bulk soil types previously (Martínez-Diz et al. 2019). Filobasidium sp., which was reported during our study as 15 th in abundance from grape roots, has been previously reported as a dominant species of vineyard rhizosphere, bulk soils, and grape roots, and may be responsible for the dissimilarity between the fungal assemblages of these substrata (Martínez-Diz et al. 2019).

Interestingly, different bacteria were recruited by the roots of Merlot grapevines growing in vineyards located in Long Island (Suffolk County, NY, U.S.A.) (Zarraonaindia et al. 2015). This region would be described as region III, according to the Winkler index; for comparison, the vineyard used in the present study would be considered a much cooler region I. Xanthomonadales, Rhizobiales, Saprospirales, Cytophagales and Actmycetales were the most abundant bacterial families enriched in Merlot root microbiomes, while our study identified Pseudomonadales, Steroidobacterales, Rhizobiales, and Micrococcales as the most abundant bacterial families enriched in the root microbiome. These differences in root-enriched taxa could be explained by the variation in the rootstock genotypes, though such drastic differences were not apparent in the present study, or by differences in vineyard management or climate.

The PGP rhizobacteria genus Pseudomonas was the dominant bacterial genus in the grape-root microbiome. Pseudomonas spp. can produce siderophores and phytohormones and are known for their nitrogen-fixation, ammonia-production, phosphate-solubilization, and biocontrol capabilities (Ferreira et al. 2019; Padda et al. 2019; Puri et al. 2020). However, not all species are beneficial; Pseudomonas syringae is a known plant pathogen that has also been linked with lowering the freezing tolerance of plant tissues through the generation of ice-nucleation activation proteins (Maki et al. 1974; Morris et al. 2008). The presence of $P$. syringae could have implications in Nova Scotia, where freezing temperatures typically penetrate deep into the soil for several months out of the year. Several Rhizobiales and Actinobacteria taxa, and Caulobacter and Pantoea genera with broad spectra of PGP characteristics, including biostimulation, biofertilization, and biocontrol (Ferreira et al. 2019), were enriched in grape roots compared with soil. Overrepresented in root tissue, Streptomyces spp. have capabilities to produce siderophores and stimulate fungi growth, improving plant phosphorus acquisition (Franco-Correa

TABLE 4

Adonis test (PERMANOVA) results to determine what proportion of the variance in the taxonomic composition of the grape roots is explained by root depth, rootstock, and the rootstock-root depth interaction ${ }^{2}$

\begin{tabular}{|c|c|c|c|c|c|c|}
\hline \multirow[b]{2}{*}{ Grouping } & \multicolumn{3}{|c|}{$16 \mathrm{~S}\left(R^{2}\right)$} & \multicolumn{3}{|c|}{ Internal transcribed spacer $\left(R^{2}\right)$} \\
\hline & Bray-Curtis & Unweighted & Weighted & Bray-Curtis & Unweighted & Weighted \\
\hline Rootstock & $0.13^{* * *}$ & $0.10 * * *$ & $0.11^{*}$ & $0.22 * *$ & $0.12^{*}$ & 0.16 \\
\hline Vine & $0.33^{* * *}$ & $0.29 *$ & 0.31 & 0.28 & $0.38^{* * *}$ & 0.35 \\
\hline Rootstock-root depth & 0.10 & 0.10 & 0.14 & 0.12 & 0.13 & 0.12 \\
\hline
\end{tabular}

${ }^{z}$ Asterisks *, ${ }^{* *}$, and ${ }^{* * *}$ indicate $P<0.05,0.01$, and 0.001 , respectively.

A Bacteria

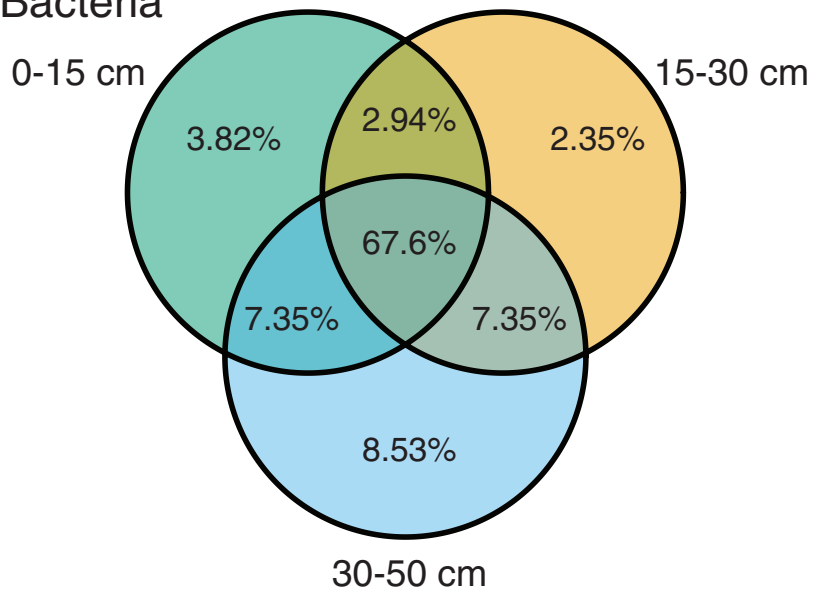

B Fungi

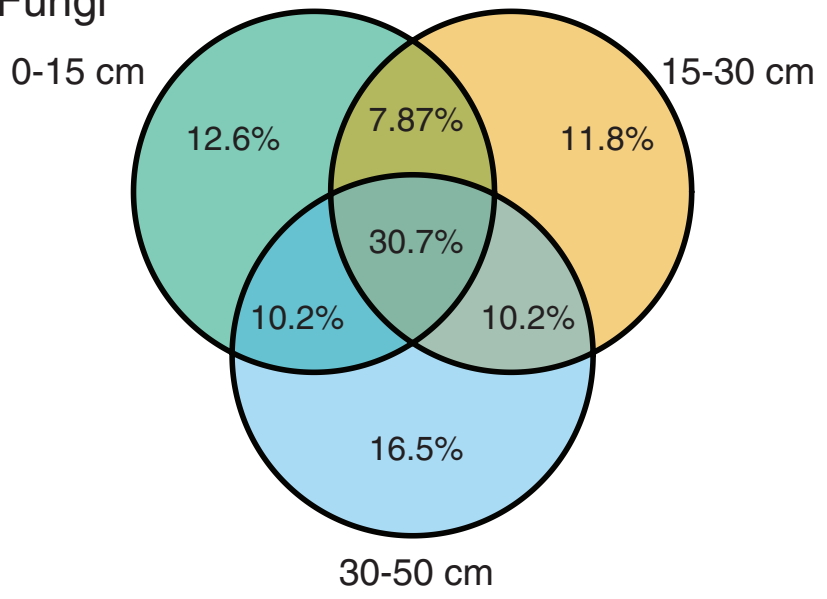

Fig. 2. Venn diagrams showing the overlap in $\mathbf{A}$, bacterial and $\mathbf{B}$, fungal genera across soil depths. 
et al. 2010). Similar to a previous report (Zarraonaindia et al. 2015), brassinosteroid-producing Steroidobacter spp., which have a potentially important role in plant development (Tang et al. 2016), and endophytic families Chitinophagaceae and Sphingomonadaceae (Armanhi et al. 2018), were found in higher abundance in grape roots than in soil. Several bacterial species with PGP and biocontrol characteristics were highly enriched in the grape-root microbiome. The RA of B. simplex, represented by $1.4 \%$ of all $16 \mathrm{~S}$ rRNA reads in the grape-root microbiome, was 143 -fold greater in grape roots compared with soils. In addition to secreting polyamines, producing siderophores, and synthesizing antimicrobial peptides and antibiotics (Maymon et al. 2015), B. simplex strains exhibit strong biocontrol activities against Fusarium infection (Khan et al. 2018). Paenibacillus amylolyticus, also overrepresented in grape roots compared with soils, can have activity against both Gram-positive and Gramnegative pathogens (Anandan and Vittal 2019) and grape-root-specific Pantoea agglomerans is a potent biocontrol agent with diverse PGP characteristics (Dutkiewicz et al. 2016). Endophyte colonization can improve plant nutrient uptake and increase plant growth and development (Ferreira et al. 2019). As a result, it is feasible that a long history of grape breeding targeting specific fruit characteristics could potentially promote the ability of the host plant to select for PGP endophytes that may help fulfill these requirements.

AMF are a minor constituent. Notably, AMF were not among the most abundant fungal genera found within any of the sample types (Fig. 1D). However, all three sample types (soil, grape roots, and cover crop roots) showed members of the phylum Glomeromycota in a subset of these samples, at least when an unfiltered denoising algorithm was used (Supplementary File S4). Interestingly, using the deblur denoising algorithm yielded higher RAs compared with unfiltered DADA2 results for all sample types. It was unexpected that AMF were not found to be a major constituent of the grape roots. Grapevines are often highly mycorrhizal and known to depend on AMF for improved water-use efficiency and soil-nutrient uptake (Possingham and Obbink 1971; Schreiner and Mihara 2009; Trouvelot et al. 2015; Valentine et al. 2006). Use of fungal ITS primers rather than AMF-specific primers may have reduced AMF identification power, although Morgan et al. (2017) suggest that the ITS region is the best marker in grapevine microbiome analyses and should sufficiently capture AMF diversity. Other research to date has searched for AMF in grapevine roots using primers optimized for Glomeromycota, and reports higher abundances of AMF (Bouffaud et al. 2016; Holland et al. 2014; Schreiner and Mihara 2009). However, other recent studies have shown that
Glomeromycota may make up only a small percentage of the total fungal species present in grape roots (Berlanas et al. 2019; Swift et al. 2021). It may be that, for the vineyard sampled in this study, high phosphorous levels (Supplementary Table S1) and the ample amount of precipitation provided by the Maritime climate are explanatory factors for the low AMF levels found in this study.

Microbiome throughout the soil column and in relation to soil parameters. Previous studies have shown that microbial composition and diversity of the soil significantly changes with soil depth (Niu et al. 2021; Upton et al. 2020). This study showed that the gradients in the microbial composition within the vertical soil column may also be a factor in the roots, especially for bacteria, albeit with a low degree of explanatory power (Table 4). Alternatively, the subtle influence of the depth from which the root was sampled on the microbiome could also simply be the result of contamination of the root samples from the soil itself.

No individual soil parameters, $\mathrm{pH}$, organic matter, $\mathrm{CEC}$, or a range of macro- and micronutrients were found to be correlated with $\alpha$-diversity metrics for either bacteria or fungi in this study. However, a lone fungi genus, Pseudaleuria, was found to be correlated with a few micronutrients. The reason for this is unknown and is in contrast to the results of $\mathrm{Xu}$ et al. (2012), who found no correlation between Pseudaleuria and soil pH, P, K, or Mg. Finally, the finding that vine root mass was found to be correlated with fungal evenness may be in keeping with past studies. If root mass may be thought of as a proxy for overall nutrient availability, previous studies found the latter influenced the overall fungal community (Lauber et al. 2008; Santos-González et al. 2011; Sun et al. 2011).

Microbiome across grape rootstock. For the grape root microbiome, rootstock was also a significant factor, albeit with low explanatory power, affecting both bacterial and fungal community structure (Table 4). It should be noted that this study did not endeavor to determine whether the act of grafting itself may be an influential factor because the root types in this study did not included self-grafted vines. The findings of this study are in agreement with past studies (Berlanas et al. 2019; D'Amico et al. 2018; St. Laurent et al. 2010; Marasco et al. 2018; Martínez-Diz et al. 2019; Swift et al. 2021; Vink et al. 2021; Warschefsky et al. 2016). A number of potential PGP and biocontrol bacteria exhibited rootstock-specific distributions in the grape-root microbiome, including Actinobacteria taxa. Endophyte colonization can affect the resistance of the plant to pathogen attack, and the ability of the plant to recruit endophytes with biocontrol properties might contribute to rootstock disease resistance. For the fungal assemblage in
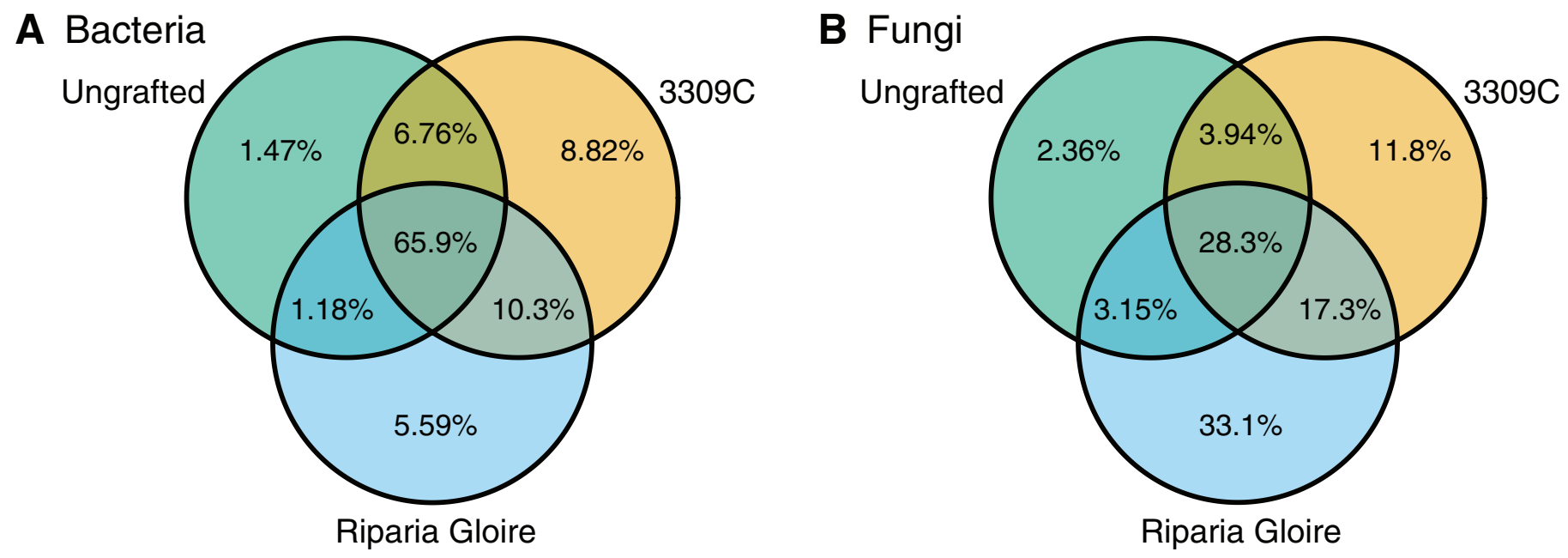

Fig. 3. Venn diagrams showing the overlap in A, bacterial and B, fungal genera between ungrafted, 3309C, and Riparia Gloire grape root types. 
particular, Berlanas et al. (2019), who found a strong association between the fungi present and rootstock genotype $\left(r^{2}=0.86, P<\right.$ 0.001 ), showed that this association was greater in older, moreestablished vines than in younger ones. The young age of the vines in the current study (approximately 5 years) could explain the low degree of explanatory power the rootstock had in its effect on the microbiome. Finally, it should be noted that the differences in bulk root mass as well as soil parameters (Supplementary Table S2) between grape root types may be a factor in the differences found in the microbiome. Although the own-rooted vines had the largest root mass, soil testing showed that these vines also had the highest organic matter and CEC levels, as well as the highest levels of key macronutrients such as $\mathrm{P}$ and $\mathrm{K}$ as well. However, it is also possible that the microbiome associated with a more extensive root system, and that of a more vegetative plant with higher levels of nutrient cycling, as in the case of the own-rooted vines, may improve the nutrient status of the soil.

\section{ACKNOWLEDGMENTS}

We thank the commercial grower who allowed us to use their vineyard and to excavate their vines; students D. Divanli, H. Machat, C. Auclair, and S. Visser; and technicians C. Bishop and E. Bevis.

\section{LITERATURE CITED}

Agustí-Brisach, C., and Armengol, J. 2013. Black-foot disease of grapevine: An update on taxonomy, epidemiology and management strategies. Phytopathol. Mediterr. 52:245-261.

Agustí-Brisach, C., Mostert, L., and Armengol, J. 2014. Detection and quantification of Ilyonectria spp. associated with black-foot disease of grapevine in nursery soils using multiplex nested PCR and quantitative PCR. Plant Pathol. 63:316-322.

Amir, A., McDonald, D., Navas-Molina, J. A., Kopylova, E., Morton, J. T., Xu, Z. Z., Kightley, E. P., Thompson, L. R., Hyde, E. R., Gonzalez, A., and Knight, R. 2017. Deblur rapidly resolves single-nucleotide community sequence patterns. mSystems 2:00191-16.

Anandan, K., and Vittal, R. R. 2019. Endophytic Paenibacillus amylolyticus KMCLE06 extracted dipicolinic acid as antibacterial agent derived via dipicolinic acid synthetase gene. Curr. Microbiol. 76:178-186.

Armanhi, J. S. L., de Souza, R. S. C., Damasceno, N. B., de Araújo, L. M., Imperial, J., and Arruda, P. 2018. A community-based culture collection for targeting novel plant growth-promoting bacteria from the sugarcane microbiome. Front. Plant Sci. 8.

Babalola, O. O., Fadiji, A. E., Enagbonma, B. J., Alori, E. T., Ayilara, M. S., and Ayangbenro, A. S. 2020. The nexus between plant and plant microbiome: Revelation of the networking strategies. Front. Microbiol. 11:2128.

Baldan, E., Nigris, S., Populin, F., Zottini, M., Squartini, A., and Baldan, B. 2014. Identification of culturable bacterial endophyte community isolated from tissues of Vitis vinifera "Glera". Plant Biosyst. 148: 508-516.

Barata, A., Malfeito-Ferreira, M., and Loureiro, V. 2012. The microbial ecology of wine grape berries. Int. J. Food Microbiol. 153:243-259.

Barka, E. A., Belarbi, A., Hachet, C., Nowak, J., and Audran, J. C. 2000 Enhancement of in vitro growth and resistance to gray mould of Vitis vinifera co-cultured with plant growth-promoting rhizobacteria. FEMS Microbiol. Lett. 186:91-95.

Berlanas, C., Berbegal, M., Elena, G., Laidani, M., Cibriain, J. F., Sagües, A., and Gramaje, D. 2019. The fungal and bacterial rhizosphere microbiome associated with grapevine rootstock genotypes in mature and young vineyards. Front. Microbiol. 10:1142.

Berruti, A., Desirò, A., Visentin, S., Zecca, O., and Bonfante, P. 2017. ITS fungal barcoding primers versus $18 \mathrm{~S}$ AMF-specific primers reveal similar AMF-based diversity patterns in roots and soils of three mountain vineyards. Environ. Microbiol. Rep. 9:658-667.

Bokulich, N. A., Collins, T. S., Masarweh, C., Allen, G., Heymann, H., Ebeler, S. E., and Millsa, D. A. 2016. Associations among wine grape microbiome, metabolome, and fermentation behavior suggest microbial contribution to regional wine characteristics. MBio 7:00631-16.

Bolyen, E., Rideout, J. R., Dillon, M. R., Bokulich, N. A., Abnet, C. C., Al-Ghalith, G. A., et al. 2019. Reproducible, interactive, scalable and extensible microbiome data science using QIIME 2. Nat. Biotechnol. 37: 852-857.

Bonito, G., Hameed, K., Ventura, R., Krishnan, J., Schadt, C. W., and Vilgalys, R. 2016. Isolating a functionally relevant guild of fungi from the root microbiome of Populus. Fungal Ecol. 22:35-42.

Bonito, G., Reynolds, H., Robeson, M. S., Nelson, J., Hodkinson, B. P., Tuskan, G., Schadt, C. W., and Vilgalys, R. 2014. Plant host and soil origin influence fungal and bacterial assemblages in the roots of woody plants. Mol. Ecol. 23:3356-3370.

Bottalico, A., and Perrone, G. 2002. Toxigenic Fusarium species and mycotoxins associated with head blight in small-grain cereals in Europe. Eur. J. Plant Pathol. 108:611-624.

Bouam, A., Armstrong, N., Levasseur, A., and Drancourt, M. 2018. Mycobacterium terramassiliense, Mycobacterium rhizamassiliense and Mycobacterium numidiamassiliense sp. nov., three new Mycobacterium simiae complex species cultured from plant roots. Sci. Rep. 8:9309.

Bouffaud, M. L., Bernaud, E., Colombet, A., Van Tuinen, D., Wipf, D., and Redecker, D. 2016. Regional-scale analysis of arbuscular mycorrhizal fungi: The case of Burgundy vineyards. J. Int. Sci. Vigne Vin 50:1-8.

Bougreau, M., Ascencio, K., Bugarel, M., Nightingale, K., and Loneragan, G. 2019. Yeast species isolated from Texas High Plains vineyards and dynamics during spontaneous fermentations of Tempranillo grapes. PLoS One 14:e0216246.

Bulgarelli, D., Schlaeppi, K., Spaepen, S., Van Themaat, E. V. L., and Schulze-Lefert, P. 2013. Structure and functions of the bacterial microbiota of plants. Annu. Rev. Plant Biol. 64:807-838.

Callahan, B. J., McMurdie, P. J., Rosen, M. J., Han, A. W., Johnson, A. J. A., and Holmes, S. P. 2016. DADA2: High-resolution sample inference from Illumina amplicon data. Nat. Methods 13:581-583.

Chapelle, E., Mendes, R., Bakker, P. A. H., and Raaijmakers, J. M. 2016. Fungal invasion of the rhizosphere microbiome. ISME J. 10:265-268.

Chen, Z., Wang, Q., Ma, J., Zou, P., Yu, Q., and Jiang, L. 2020. Fungal community composition change and heavy metal accumulation in response to the long-term application of anaerobically digested slurry in a paddy soil. Ecotoxicol. Environ. Saf. 196:110453.

Comeau, A. M., Douglas, G. M., and Langille, M. G. I. 2017. Microbiome helper: A custom and streamlined workflow for microbiome research. mSystems 2:11.

Comitini, F., and Ciani, M. 2008. Influence of fungicide treatments on the occurrence of yeast flora associated with wine grapes. Ann. Microbiol. 58: 489-493.

D’Amico, F., Candela, M., Turroni, S., Biagi, E., Brigidi, P., Bega, A., Vancini, D., and Rampelli, S. 2018. The rootstock regulates microbiome diversity in root and rhizosphere compartments of Vitis vinifera cultivar Lambrusco. Front. Microbiol. 9:2240.

Dutkiewicz, J., Mackiewicz, B., Lemieszek, M. K., Golec, M., and Milanowski, J. 2016. Pantoea agglomerans: A mysterious bacterium of evil and good. Part IV. Beneficial effects. Ann. Agric. Environ. Med. 23:206-222.

Fahrbach, M., Kuever, J., Remesch, M., Huber, B. E., Kämpfer, P., Dott, W., and Hollender, J. 2008. Steroidobacter denitrificans gen. nov., sp. nov., a steroidal hormone-degrading gammaproteobacterium. Int. J. Syst. Evol. Microbiol. 58:2215-2223.

Farh, M. E. A., Kim, Y. J., Kim, Y. J., and Yang, D. C. 2018. Cylindrocarpon destructans/Ilyonectria radicicola-species complex: Causative agent of ginseng root-rot disease and rusty symptoms. J. Ginseng Res. 42:9-15.

Fernandes, A. D., Macklaim, J. M., Linn, T. G., Reid, G., and Gloor, G. B. 2013. ANOVA-like differential expression (ALDEx) analysis for mixed population RNA-Seq. PLoS One 8:e67019.

Ferreira, C. M. H., Soares, H. M. V. M., and Soares, E. V. 2019. Promising bacterial genera for agricultural practices: An insight on plant growthpromoting properties and microbial safety aspects. Sci. Total Environ. 682:779-799.

Franco-Correa, M., Quintana, A., Duque, C., Suarez, C., Rodríguez, M. X., and Barea, J. M. 2010. Evaluation of actinomycete strains for key traits related with plant growth promotion and mycorrhiza helping activities. Appl. Soil Ecol. 45:209-217. 
Gerőcs, A., Pál, S., Szőke, B., Májer, J., and Olasz, F. 2016. Analysis of the soil microbial community in the Badascony wine region. N. Biotechnol. 33:S126.

Gkarmiri, K., Mahmood, S., Ekblad, A., Alström, S., Högberg, N., and Finlay, R. 2017. Identifying the active microbiome associated with roots and rhizosphere soil of oilseed rape. Appl. Environ. Microbiol. 83:01938-17.

González, V., and Tello, M. L. 2011. The endophytic mycota associated with Vitis vinifera in central Spain. Fungal Divers. 47:29-42.

González-García, S., Álvarez-Pérez, J. M., Sáenz de Miera, L. E., Cobos, R. Ibañez, A., Díez-Galán, A., Garzón-Jimeno, E., and Coque, J. J. R. 2019. Developing tools for evaluating inoculation methods of biocontrol Streptomyces sp. strains into grapevine plants. PLoS One 14:e0211225.

Gramaje, D., Urbez-Torres, J. R., and Sosnowski, M. R. 2018. Managing grapevine trunk diseases with respect to etiology and epidemiology: Current strategies and future prospects. Plant Dis. 102:12-39.

Grelet, G. A., Ba, R., Goeke, D. F., Houliston, G. J., Taylor, A. F. S., and Durall, D. M. 2017. A plant growth-promoting symbiosis between Mycena galopus and Vaccinium corymbosum seedlings. Mycorrhiza 27:831-839.

Hacquard, S., Garrido-Oter, R., González, A., Spaepen, S., Ackermann, G., Lebeis, S., McHardy, A. C., Dangl, J. L., Knight, R., Ley, R., and Schulze-Lefert, P. 2015. Microbiota and host nutrition across plant and animal kingdoms. Cell Host Microbe 17:603-616.

Halleen, F., Fourie, P. H., and Crous, P. W. 2006. A review of black foot disease of grapevine. Phytopathol. Mediterr. 45:S55-S67.

Himstedt, R., Wagner, S., Jaeger, R. J. R., Lieunang Watat, M. L., Backenköhler, J., Rupcic, Z., Stadler, M., and Spiteller, P. 2020. Formaldehyde as a chemical defence agent of fruiting bodies of Mycena rose $a$ and its role in the generation of the alkaloid Mycenarubin $\mathrm{C}$. ChemBioChem 21:1613-1620.

Holland, T. C., Bowen, P., Bogdanoff, C., and Hart, M. 2014. Arbuscular mycorrhizal fungal communities associated with Vitis vinifera vines under different frequencies of irrigation. Am. J. Enol. Vitic. 65:222-229.

Holmstrom, D. A., and Thompson, B. L. 1989. Soils of the Annapolis Valley area of Nova Scotia. Report No. 22. Page 243.

Katoh, K., and Standley, D. M. 2013. MAFFT multiple sequence alignment software version 7: Improvements in performance and usability. Mol. Biol. Evol. 30:772-780

Khan, N., Martínez-Hidalgo, P., Ice, T. A., Maymon, M., Humm, E. A., Nejat, N., Sanders, E. R., Kaplan, D., and Hirsch, A. M. 2018. Antifunga activity of bacillus species against fusarium and analysis of the potential mechanisms used in biocontrol. Front. Microbiol. 9:2363.

Kim, S. J., Ahn, J. H., Weon, H. Y., Hong, S. B., Seok, S. J., Kim, J. S., and Kwon, S. W. 2015. Niastella gongjuensis sp. nov., isolated from greenhouse soil. Int. J. Syst. Evol. Microbiol. 65:3115-3118.

Kolton, M., Frenkel, O., Elad, Y., and Cytryn, E. 2014. Potential role of flavobacterial gliding-motility and type IX secretion system complex in root colonization and plant defense. Mol. Plant-Microbe Interact. 27:1005-1013.

Lauber, C. L., Strickland, M. S., Bradford, M. A., and Fierer, N. 2008. The influence of soil properties on the structure of bacterial and fungal communities across land-use types. Soil Biol. Biochem. 40:2407-2415.

Leuchtmann, A., and Clémençon, H. 2012. The taxonomic position of the genus Heydenia (Pyronemataceae, Pezizales) based on molecular and morphological data. Mycol. Prog. 11:699-710.

Liang, H., Wang, X., Yan, J., and Luo, L. 2019. Characterizing the intravineyard variation of soil bacterial and fungal communities. Front. Microbiol. 10:1239.

Linderman, R. G., and Davis, E. A. 2001. Comparative response of selected grapevine rootstocks and cultivars to inoculation with different mycorrhizal fungi. Am. J. Enol. Vitic. 52:8-11.

Lombard, L., van der Merwe, N. A., Groenewald, J. Z., and Crous, P. W. 2015. Generic concepts in Nectriaceae. Stud. Mycol. 80:189-245.

Lorenzini, M., and Zapparoli, G. 2014. Characterization and pathogenicity of Alternaria spp. strains associated with grape bunch rot during post-harvest withering. Int. J. Food Microbiol. 186:1-5.

Lorenzini, M., and Zapparoli, G. 2019. Yeast-like fungi and yeasts in withered grape carposphere: Characterization of Aureobasidium pullulans population and species diversity. Int. J. Food Microbiol. 289:223-230.

Lundberg, D. S., Lebeis, S. L., Paredes, S. H., Yourstone, S., Gehring, J., Dangl, J. L., and Tringe, S. G. 2012. Defining the core Arabidopsis thaliana root microbiome. Nature 488:86-90.

Luo, D., Langendries, S., Mendez, S. G., De Ryck, J., Liu, D., Beirinckx, S. Willems, A., Russinova, E., Debode, J., and Goormachtig, S. 2019. Plant growth promotion driven by a novel Caulobacter strain. Mol. PlantMicrobe Interact. 32:1162-1174.
Maki, L. R., Galyan, E. L., Chang-Chien, M. M., and Caldwell, D. R. 1974. Ice nucleation induced by Pseudomonas syringae. Appl. Microbiol. 28:456-459.

Maldonado-González, M. M., Martínez-Diz, M. D. P., Andrés-Sodupe, M. Bujanda, R., Díaz-Losada, E., and Gramaje, D. 2020. Quantification of Cadophora luteo-olivacea from grapevine nursery stock and vineyard soil using droplet digital PCR. Plant Dis. 104:2269-2274.

Marasco, R., Rolli, E., Fusi, M., Michoud, G., and Daffonchio, D. 2018. Grapevine rootstocks shape underground bacterial microbiome and networking but not potential functionality. Microbiome 6:3

Marotz, C., Amir, A., Humphrey, G., Gaffney, J., Gogul, G., and Knight, R. 2017. DNA extraction for streamlined metagenomics of diverse environmental samples. Biotechniques 62:290-293.

Martin, M. 2011. Cutadapt removes adapter sequences from high-throughput sequencing reads. EMBnet. J. 17:10.

Martínez-Diz, M. D. P., Andrés-Sodupe, M., Bujanda, R., Díaz-Losada, E., Eichmeier, A., and Gramaje, D. 2019. Soil-plant compartments affect fungal microbiome diversity and composition in grapevine. Fungal Ecol. 41:234-244.

Marzano, M., Fosso, B., Manzari, C., Grieco, F., Intranuovo, M., Cozzi, G., Mulè, G., Scioscia, G., Valiente, G., Tullo, A., Sbisà, E., Pesole, G., and Santamaria, M. 2016. Complexity and dynamics of the winemaking bacterial communities in berries, musts, and wines from Apulian grape cultivars through time and space. PLoS One 11:e0157383.

Maymon, M., Martínez-Hidalgo, P., Tran, S. S., Ice, T., Craemer, K., Anbarchian, T., Sung, T., Hwang, L. H., Chou, M., Fujishige, N. A., Villella, W., Ventosa, J., Sikorski, J., Sanders, E. R., Faull, K. F., and Hirsch, A. M. 2015. Mining the phytomicrobiome to understand how bacterial coinoculations enhance plant growth. Front. Plant Sci. 6:784.

Mezzasalma, V., Sandionigi, A., Guzzetti, L., Galimberti, A., Grando, M. S. Tardaguila, J., and Labra, M. 2018. Geographical and cultivar features differentiate grape microbiota in Northern Italy and Spain vineyards. Front. Microbiol. 9:946.

Miura, T., Sánchez, R., Castañeda, L. E., Godoy, K., and Barbosa, O. 2017. Is microbial terroir related to geographic distance between vineyards? Environ. Microbiol. Rep. 9:742-749.

Moll, J., Hoppe, B., König, S., Wubet, T., Buscot, F., and Krüger, D. 2016. Spatial distribution of fungal communities in an arable soil. PLoS One 11: e0148130.

Moloinyane, S., Addison, P., Achiano, K. A., and Nchu, F. 2020. Association between chemical properties of vineyard soils and occurrence of entomopathogenic fungi causing different levels of mortality in Planococcus ficus. BioControl 65:197-209.

Morgan, H. H., du Toit, M., and Setati, M. E. 2017. The grapevine and wine microbiome: Insights from high-throughput amplicon sequencing. Front. Microbiol. 8:820.

Morris, C. E., Sands, D. C., Vinatzer, B. A., Glaux, C., Guilbaud, C. Buffière, A., Yan, S., Dominguez, H., and Thompson, B. M. 2008. The life history of the plant pathogen Pseudomonas syringae is linked to the water cycle. ISME J. 2:321-334.

Naugler, C., Wright, B., and Murray, R. 2004. The Tangled Vine: Winegrowing in Nova Scotia. Blue Frog Inc., Bridgewater, Nova Scotia, Canada.

Nelson, P. E., Dignani, M. C., and Anaissie, E. J. 1994. Taxonomy, biology, and clinical aspects of Fusarium species. Clin. Microbiol. Rev. 7: 479-504.

Nilsson, R. H., Larsson, K. H., Taylor, A. F. S., Bengtsson-Palme, J., Jeppesen, T. S., Schigel, D., Kennedy, P., Picard, K., Glöckner, F. O., Tedersoo, L., Saar, I., Kõljalg, U., and Abarenkov, K. 2019. The UNITE database for molecular identification of fungi: Handling dark taxa and parallel taxonomic classifications. Nucleic Acids Res. 47:D259-D264.

Nirenberg, H. I., and O'Donnell, K. 1998. New Fusarium species and combinations within the Gibberella fujikuroi species complex. Mycologia 90:434-458.

Niu, G., Hasi, M., Wang, R., Wang, Y., Geng, Q., Hu, S., Xu, X., Yang, J., Wang, C., Han, X., and Huang, J. 2021. Soil microbial community responses to long-term nitrogen addition at different soil depths in a typical steppe. Appl. Soil Ecol. 167:104054.

O'Donnell, K. 2000. Molecular phylogeny of the Nectria haematococca-Fusarium solani species complex. Mycologia 92:919-938.

Padda, K. P., Puri, A., and Chanway, C. 2019. Endophytic nitrogen fixationA possible 'hidden' source of nitrogen for lodgepole pine trees growing at unreclaimed gravel mining sites. FEMS Microbiol. Ecol. 95:fiz172.

Pascale, A., Proietti, S., Pantelides, I. S., and Stringlis, I. A. 2020. Modulation of the root microbiome by plant molecules: The basis for targeted disease suppression and plant growth promotion. Front. Plant Sci. 10:1741. 
Petit, E., and Gubler, W. D. 2005. Characterization of Cylindrocarpon species, the cause of black foot disease of grapevine in California. Plant Dis. 89:1051-1059.

Pinto, C., and Gomes, A. C. 2016. Vitis vinifera microbiome: From basic research to technological development. BioControl 61:243-256.

Portillo, M. C., Franquès, J., Araque, I., Reguant, C., and Bordons, A. 2016. Bacterial diversity of Grenache and Carignan grape surface from differen vineyards at Priorat wine region (Catalonia, Spain). Int. J. Food Microbiol. 219:56-63.

Possingham, J. V., and Obbink, J. G. 1971. Endotropic mycorrhiza and the nutrition of grape vines. Vitis 10:120-130.

Price, M. N., Dehal, P. S., and Arkin, A. P. 2010. FastTree 2-Approximately maximum-likelihood trees for large alignments. PLoS One 5:e9490.

Puri, A., Padda, K. P., and Chanway, C. P. 2020. Can naturally-occurring endophytic nitrogen-fixing bacteria of hybrid white spruce sustain boreal forest tree growth on extremely nutrient-poor soils? Soil Biol. Biochem. 140:107642.

Quast, C., Pruesse, E., Yilmaz, P., Gerken, J., Schweer, T., Yarza, P., Peplies, J., and Glöckner, F. O. 2013. The SILVA ribosomal RNA gene database project: Improved data processing and web-based tools. Nucleic Acids Res. 41:D590-D596.

Ramos, B., González-Melendi, P., Sánchez-Vallet, A., Sánchez-Rodríguez, C., López, G., and Molina, A. 2013. Functional genomics tools to decipher the pathogenicity mechanisms of the necrotrophic fungus Plectosphaerella cucumerina in Arabidopsis thaliana. Mol. Plant Pathol. 14:44-57.

R Core Team. 2019. The R Project for Statistical Computing, version-3.5.3. https://www.r-project.org/

Rego, C., Oliveira, H., Carvalho, A., and Phillips, A. 2000. Involvement of Phaeoacremonium spp. and Cylindrocarpon destructans with grapevine decline in Portugal. Phytopathol. Mediterr. 39:76-79.

Rimerman, A. F. 2015. The Economic Impact of the Wine and Grape Industry in Canada 2015. Frank, Rimerman + Co. LLP, St. Helena, CA, U.S.A.

Rognes, T., Flouri, T., Nichols, B., Quince, C., and Mahé, F. 2016. VSEARCH: A versatile open source tool for metagenomics. PeerJ 4:e2584.

Salvetti, E., Campanaro, S., Campedelli, I., Fracchetti, F., Gobbi, A., Tornielli, G. B., Torriani, S., and Felis, G. E. 2016. Whole-metagenomesequencing-based community profiles of Vitis vinifera L. cv. Corvina berries withered in two post-harvest conditions. Front. Microbiol. 7:937.

Samad, A., Trognitz, F., Compant, S., Antonielli, L., and Sessitsch, A. 2017 Shared and host-specific microbiome diversity and functioning of grapevine and accompanying weed plants. Environ. Microbiol. 19:1407-1424.

Santos-González, J. C., Nallanchakravarthula, S., Alström, S., and Finlay, R. D. 2011. Soil, But Not Cultivar, shapes the structure of arbuscular mycorrhizal fungal assemblages associated with strawberry. Microb. Ecol. 62:25-35.

Schmidt, S. K., Vimercati, L., Darcy, J. L., Arán, P., Gendron, E. M. S., Solon, A. J., Porazinska, D., and Dorador, C. 2017. A Naganishia in high places: Functioning populations or dormant cells from the atmosphere? Mycol. 8:153-163.

Schoch, C. L., Seifert, K. A., Huhndorf, S., Vincent, R., Spouge, J. L., Levesque, C. A., Chen, W., and Fungal Barcoding Consortium. 2012. Nuclear ribosomal internal transcribed spacer (ITS) region as a universal DNA barcode marker for Fungi. Proc. Natl. Acad. Sci. U.S.A. 109:6241-6246.

Schreiner, R. P., and Mihara, K. L. 2009. The diversity of arbuscular mycorrhizal fungi amplified from grapevine roots (Vitis vinifera L.) in Oregon vineyards is seasonally stable and influenced by soil and vine age. Mycologia 101:599-611.

Soil Classification Working Group. 1987. The Canadian System of Soil Classification. National Research Council of Canada, Ottawa, ONT, Canada.

St. Laurent, A., Merwin, I. A., Fazio, G., Thies, J. E., and Brown, M. G. 2010. Rootstock genotype succession influences apple replant disease and root-zone microbial community composition in an orchard soil. Plant Soil 337:259-272.

Stosiek, N., Terebieniec, A., Ząbek, A., Młynarz, P., Cieśliński, H., and KlimekOchab, M. 2019. N-phosphonomethylglycine utilization by the psychrotolerant yeast Solicoccozyma terricola M 3.1.4. Bioorg. Chem. 93:102866.

Sun, Q., Sacks, G., Lerch, S., and Vanden Heuvel, J. E. 2011. Impact of shoot thinning and harvest date on yield components, fruit composition, and wine quality of Marechal Foch. Am. J. Enol. Vitic. 62:32-41.

Swift, J. F., Hall, M. E., Harris, Z. N., Kwasniewski, M. T., and Miller, A. J. 2021. Grapevine microbiota reflect diversity among compartments and complex interactions within and among root and shoot systems. Microorganisms 9:92.
Tang, J., Han, Z., and Chai, J. 2016. Q\&A: What are brassinosteroids and how do they act in plants. BMC Biol. 14

Tedersoo, L., Sánchez-Ramírez, S., Kõljalg, U., Bahram, M., Döring, M., Schigel, D., May, T., Ryberg, M., and Abarenkov, K. 2018. High-level classification of the Fungi and a tool for evolutionary ecological analyses. Fungal Divers. 90:135-159.

Thoen, E., Harder, C. B., Kauserud, H., Botnen, S. S., Vik, U., Taylor, A. F. S., Menkis, A., and Skrede, I. 2020. In vitro evidence of root colonization suggests ecological versatility in the genus Mycena. New Phytol. 227:601-612.

Toju, H., Tanabe, A. S., and Sato, H. 2018. Network hubs in root-associated fungal metacommunities. Microbiome 6:116.

Torcato, C., Gonçalves, M. F. M., Rodríguez-Gálvez, E., and Alves, A. 2020. Clonostachys viticola sp. nov., a novel species isolated from Vitis vinifera. Int. J. Syst. Evol. Microbiol. 70:4321-4328.

Trail, F., and Common, R. 2000. Perithecial development by Gibberella zeae: A light microscopy study. Mycologia 92:130-138.

Traquair, J. A., and White, G. P. 1992. Cylindrocarpon rot of fruit trees in cold storage. Can. J. Plant Pathol. 14:310-314.

Trouvelot, S., Bonneau, L., Redecker, D., van Tuinen, D., Adrian, M., and Wipf, D. 2015. Arbuscular mycorrhiza symbiosis in viticulture: A review. Agron. Sustain. Dev. 35:1449-1467.

Unestam, T., Beyer-Ericson, L., and Strand, M. 1989. Involvement of Cylindrocarpon destructans in root death of Pinus sylvestris seedlings: Pathogenic behaviour and predisposing factors. Scand. J. For. Res. 4:521-535

Upton, R. N., Checinska Sielaff, A., Hofmockel, K. S., Xu, X., Polley, H. W., and Wilsey, B. J. 2020. Soil depth and grassland origin cooperatively shape microbial community co-occurrence and function. Ecosphere 11:e02973.

Úrbez-Torres, J. R., Haag, P., Bowen, P., and O'Gorman, D. T. 2014. Grapevine trunk diseases in British Columbia: Incidence and characterization of the fungal pathogens associated with black foot disease of grapevine. Plant Dis. 98:456-468.

Valentine, A. J., Mortimer, P. E., Lintnaar, M., and Borgo, R. 2006. Drought responses of arbuscular mycorrhizal grapevines. Symbiosis 41:127-133.

Vandenkoornhuyse, P., Quaiser, A., Duhamel, M., Le Van, A., and Dufresne, A. 2015. The importance of the microbiome of the plant holobiont. New Phytol. 206:1196-1206.

Vink, S. N., Dini-Andreote, F., Höfle, R., Kicherer, A., and Salles, J. F. 2021. Interactive effects of scion and rootstock genotypes on the root microbiome of grapevines (Vitis spp. L.). Appl. Sci. (Basel) 11:1615.

Visioli, G., Sanangelantoni, A. M., Vamerali, T., Dal Cortivo, C., and Blandino, M. 2018. 16S rDNA profiling to reveal the influence of seedapplied biostimulants on the rhizosphere of young maize plants. Molecules 23:1461.

Warschefsky, E. J., Klein, L. L., Frank, M. H., Chitwood, D. H., Londo, J. P., von Wettberg, E. J. B., and Miller, A. J. 2016. Rootstocks: Diversity, domestication, and impacts on shoot phenotypes. Trends Plant Sci. 21:418-437.

Wei, Y.-j., Wu, Y., Yan, Y.-z., Zou, W., Xue, J., Ma, W.-r., Wang, W., Tian, G., and Wang, L.-y. 2018. High-throughput sequencing of microbial community diversity in soil, grapes, leaves, grape juice and wine of grapevine from China. PLoS One 13:e0193097.

Woudenberg, J. H. C., Groenewald, J. Z., Binder, M., and Crous, P. W. 2013. Alternaria redefined. Stud. Mycol. 75:171-212.

Xu, L. 2011. Soil Fungal Communities Associated with Plant Health as Revealed by Next-Generation Sequencing. Aarhus University, Aarhus, Denmark.

Xu, L., Ravnskov, S., Larsen, J., Nilsson, R. H., and Nicolaisen, M. 2012. Soil fungal community structure along a soil health gradient in pea fields examined using deep amplicon sequencing. Soil Biol. Biochem. 46: 26-32.

Yurgel, S. N., Douglas, G. M., Dusault, A., Percival, D., and Langille, M. G. I. 2018. Dissecting community structure in wild blueberry root and soil microbiome. Front. Microbiol. 9:1187.

Yurkov, A. M. 2018. Yeasts of the soil-Obscure but precious. Yeast 35:369-378.

Zarraonaindia, I., Owens, S. M., Weisenhorn, P., West, K., HamptonMarcell, J., Lax, S., Bokulich, N. A., Mills, D. A., Martin, G., Taghavi, S., van der Lelie, D., and Gilbert, J. A. 2015. The soil microbiome influences grapevine-associated microbiota. MBio 6:02527-14.

Zhang, L., Gao, J. S., Kim, S. G., Zhang, C. W., Jiang, J. Q., Ma, X. T., Zhang, J., and Zhang, X. X. 2016. Novosphingobium oryzae sp. nov., a potential plant-promoting endophytic bacterium isolated from rice roots. Int. J. Syst. Evol. Microbiol. 66:302-307. 